\title{
Mikro E-Etkileyici Kişi Bağlamında Marka Tutumu Oluşumu ${ }^{1}$
}

\author{
Aydan Ünlükaya \\ Araştırma Görevlis \\ İstanbul Gelişim Üniversitesi \\ İktisadi İdari ve Sosyal Bilimler Fakültesi \\ Reklamcllık Bölümü \\ aunlukaya@gelisim.edu.tr \\ ORCID: 0000-0002-5645-6192 \\ Nurhan Zeynep Tosun \\ Prof. Dr. \\ Fenerbahçe Üniversitesi Illetişim Fakültesi \\ Halkla Ilişkiler ve Reklamcılık Bölümü \\ nurhan.tosun@fbu.edu.tr \\ ORCID: 0000-0003-0234-9647
}

\section{Abstract}

\section{Brand Attitude Creation in the Context of Micro-Influencer}

It is essential to reach a specific target audience with similar characteristics through messages that will meet their expectations for achieving the goals in creating a brand attitude. This study mainly aims; to evaluate the relationship between consumer's attitudes towards brands, which use micro-influencers in their communication campaigns on Instagram. Additionally, it was aimed to determine the consumer's demographic characteristics, their daily Instagram usage frequency, the number of micro-influencers they follow on Instagram, finding micro-influencers reliable, and their purchase status of a product recommended by the micro-influencers. In the present study, following a quantitative approach, a face-to-face questionnaire technique was used to obtain objective results by specifying the figures to be analyzed statistically. According to the research findings, women have a more positive attitude towards brands that use micro-influencers than men. Besides, findings showed that consumers who spend 4 hours or more time on Instagram and following 10 or more micro-influenc-

1 Bu makale, Prof. Dr. Nurhan Zeynep Tosun'un danışmanlığında, Aydan Ünlükaya'nın Marmara Üniversitesi Sosyal Bilimler Enstitüsü'nde hazırladığı "Mikro E-Etkileyici Kişi Kullanımının Marka Tutumu Üzerindeki Rolü" başlıkı yüksek lisans tezinden üretilmiştir. 
ers find micro-influencers trustworthy, and purchasing products recommended by these people have more positive attitudes towards brands that cooperate with micro-influencers.

keywords: Word of mouth marketing, micro, influencer, influencer marketing, brand attitude

\section{Résumé}

\section{La formation d'attitude envers la marque dans le contexte du micro influenceur}

Pour pouvoir former une attitude envers une marque, il est important d'atteindre un public qui conforme aux objectifs, un public cible spécifique ayant des caractéristiques similaires; et il est important de les atteindre avec des messages qui répondent à leurs attentes. Dans ce contexte, cette recherche vise à déterminer la relation entre les achats des consommateurs et plusieurs différents déterminants : les produits qui sont suggérés par des influenceurs, les caractéristiques démographiques des consommateurs, leurs attitudes envers les marques qui utilisent le micro-influenceur dans leurs campagnes de communication sur Instagram, le temps qu'ils passent quotidiennement sur Instagram, le nombre de micro-influenceurs qu'ils suivent, leurs critères pour déterminer un micro-influenceur fiable. Afin d'obtenir des résultats objectifs en collectant des chiffres à analyser statistiquement, la recherche est basée sur des questionnaires réalisés face à face. Selon les résultats, les femmes ont une attitude plus positive que les hommes envers les marques utilisant un micro-influenceur. De plus, les consommateurs qui passent quatre heures et plus sur Instagram, qui suivent dix micro-influenceurs et plus, qui trouvent les micro-influenceurs fiables et qui achètent les produits qu'ils recommandent ont des attitudes plus positives envers les marques qui travaillent avec les influenceurs.

mots-clés: Marketing bouche-à-oreille, micro-influenceur, marketing d'influence, attitude envers la marque 


\section{Öz}

Marka tutumu yaratmada benzer özelliklere sahip, spesifik ve amaçlara ulaşma açısından doğru hedef kitleye, beklentilerini karşılayacak mesajlarla ulaşmak önemlidir. Bu bağlamda bu araştırmada; tüketicilerin Instagram'daki iletişim kampanyalarında mikro e-etkileyici kişi kullanan markalara yönelik tutumları ile demografik durumları, günlük Instagram kullanma sıklıkları, Instagram'da takip ettikleri mikro e-etkileyici kişi sayısı, mikro e-etkileyici kişileri güvenilir bulma durumları ve mikro e-etkileyici kişilerin önerdikleri bir ürünü satın alma durumları arasındaki ilişkinin belirlenmesi amaçlanmıştır. Istatistiksel analiz uygulanacak rakamları elde ederek objektif sonuçlar saptamak için nicel araştırma kapsamında yer alan çalışmada yüz yüze anket yönteminden yararlanılmıştır. Araştırmanın bulgularına göre, kadınlar erkeklere göre mikro e-etkileyici kişi kullanan markalara karşı daha olumlu bir tutum sergilemektedir. Ayrıca Instagram'da 4 saat ve üzerinde vakit geçiren, 10 kişi ve üzerinde mikro e-etkileyici kişiyi takip eden, mikro e-etkileyici kişileri güvenilir bulan ve bu kişilerin tavsiye ettikleri ürünleri satın alan tüketicilerin, mikro e-etkileyici kişilerle iş birliği yapan markalara yönelik tutumlarının daha olumlu olduğu görülmektedir.

anahtar kelimeler: Ağızdan ağıza pazarlama, mikro, e-etkileyici kişi, e-etkileyici kişi pazarlaması, marka tutumu 


\section{Giriş}

Günümüzde, iletişim teknolojilerinin değişimi ve gelişimiyle birlikle tüketicilerin gündelik yaşamlarında yoğun reklam mesajına maruz kalmalarının yanı sıra intiyaçlarını karşılayabilecek aynı kategorideki mal ve hizmetlerin çok miktarda olması, zamanı kısıtlı olan tüketicilerin bu reklam mesajları doğrultusunda karar vermesini oldukça zor hale getirmektedir. Bu nedenle markalar, tüketicilerin daha hızlı ve kolay bir şekilde karar verebilmesi için, olumlu duygular hissettikleri kişilerden aldıkları tavsiyelere dayanan ağızdan ağıza pazarlamayı sıklıkla kullanmaktadır. Tüketicileri etkileyebilecek güce sahip olan bu kaynaklar, mevcut veya piyasaya yeni çıkan ürünleri kullanarak bu ürünler ile ilgili olumlu veya olumsuz deneyimlerini tüketicilere aktarmaktadır. Bu doğrultuda, genellikle tüketicilerin çevresindeki kişilerden oluşan kaynakların verdikleri tavsiyelerin, bireylerin satın alma kararlarını etkileyebildiği söylenebilmektedir.

Internet teknolojilerindeki ilerlemeler, sosyal medya platformlarında içeriklerin bireyler tarafından sadece tüketilmesine değil aynı zamanda üretilmesine de olanak sağlamaktadır. Bireylerin sosyal medya platformlarını günlük hayatlarında sıklıkla kullanmaya başlaması ve içerik üreticisi konumuna gelmesi bilgi alışverişinin yüz yüze gerçekleşmesine alternatif olarak çevrimiçi bir şekilde gerçekleşebilmesine de olanak sağlamaktadır. Tüketiciler, sosyal medya platformları ile bilgilerini, düşüncelerini ve deneyimlerini kendi sosyal ağındaki kişilerle sıklıkla paylaşmaktadır. Bu platformlarda yayılan mesajlar, bireylerin çevresindeki veya kendi ilgi alanına göre takip ettiği kişilere ait olduğu için, tüketicilere daha güvenilir gelmekte ve satın alma kararlarını etkileyebilmektedir. Bu nedenle markalar için, sosyal medyada ürettiği içerikler ile kendi takipçi kitlesini oluşturan ve düşünceleri ve deneyimleri ile insanları etkileyebilme gücüne sahip olan kişiler bir pazarlama iletişimi aracı haline gelmiştir. Bu durum doğrultusunda ağızdan ağıza pazarlamanın bir yöntemi olarak "Influencer Marketing" kavramı ortaya çıkmıştır. Bu çalışma kapsamında "Influencer Marketing" kavramı, sosyal medya platformlarında takipçilerinin düşüncelerini etkileyebilme gücüne sahip olan kişilerin açıkça ifade edilebilmesi için "E-etkileyici Kişi Pazarlaması" olarak Türkçeleştirilmiştir. Sosyal medyanın kanaat önderleri konumunda olan e-etkileyici kişiler markalar tarafından belirlenerek markanın ürünleri hakkında takipçilerine deneyimlerini aktarmaktadır. Böylelikle e-etkileyici kişi ve takipçi kitlesi arasındaki güven bağı tüketicilerin markaya karşı olan tutumuna olumlu bir şekilde yansıyabilmektedir.

Son yıllarda e-etkileyici kişi pazarlaması yöntemi markalar tarafından sıklıkla kullanımaktadır. Özellikle daha az takipçi kitlesine sahip olan e-etkileyici kişilerin takipçileri ile birebir konuşabilmeleri, bu kişilerin tüketiciler tarafından daha güvenilir olarak algılanmasını ve tüketicilerin bu kişilerle kendilerini özdeşleştirebilmelerini sağlamaktadır. Bu nedenle günümüzde bazı ülkelerdeki markalar mikro düzeydeki e-etkileyici kişiler ile iş birliği yapmaya başlamıştır (Gallegos, 2018; Mediakix, 2017). 
Markaların iletişim kampanyalarında yoğun kullandığı bir yöntem olan e-etkileyici kişi pazarlaması, farklı sosyal medya mecralarında yapılmaktadır. E-etkileyici kişi pazarlaması platformu olan Linqia'nın $(2017$, s. 8) yayınladığı “The State of Influencer Marketing 2018" raporuna göre, 2018'de e-etkileyici kişi pazarlamasının en çok yapıldığı mecra olarak \%92 ile Instagram belirlenmiştir. Bu doğrultuda, bu çalışma için Instagram mecrası seçilmiştir. Olabildiğince spesifik ve amaçlar açısından doğru bir hedef kitleye, beklentilerini karşılayacak mesajlarla ulaşmanın marka tutumu yaratmadaki önemi, Instagram kullanan kitlelerin çeşitli özellikleri ile marka tutumu oluşumu arasında anlamlı bir farklılığın olup olmadığının saptanmasını gerekli kılmaktadır. Bu bağlamda çalışmanın temel amacı; mikro e-etkileyici kişilerle iş birliği yapmak isteyen markalara yol gösterici olabilmek ve ilgili literatüre bu doğrultuda katkı sunmak için, tüketicilerin Instagram'daki iletişim kampanyalarında mikro e-etkileyici kişi kullanan markalara yönelik tutumları ile demografik durumları, günlük Instagram kullanma sıklıkları, Instagram'da takip edilen mikro e-etkileyici kişi sayısı, mikro e-etkileyici kişileri güvenilir bulma durumları ve mikro e-etkileyici kişilerin önerdikleri bir ürünü satın alma durumları arasında anlamlı bir farklılığın var olup olmadığını tespit etmektir.

\section{Mikro E-Etkileyici Kişi Kavramı}

Ağızdan Ağıza Pazarlama Derneği (The Word of Mouth Marketing Association), ağızdan ağıza pazarlamayı; "insanlara, mallar ve hizmetler hakkında konuşmaları adına bir neden vermek ve bu konuşmanın gerçekleştirilmesini kolaylaştırmak" şeklinde ifade etmektedir. Ağızdan ağıza iletişim sürecinde insanlar, beğendikleri veya beğenmedikleri ürünleri etrafındaki diğer insanlarla paylaşmaktadırlar. Buradaki kaynak konumundaki kişiler arkadaşlar, aile üyeleri, komşular veya tanıdık kişiler olabileceği gibi kurumun kendisi tarafından belirlenen kişiler de olabilmektedir. Dobele (2002, s. 673), kaynak konumundaki kişiler için kanaat önderleri, menfaat bekleyenler, faydalı arkadaşlar, karşılıkta bulunanlar ve ağzı kapalılar tanımlarını kullanmıştır. Walsh vd. (2004, s. 109), bu tanımlara ilave olarak pazarlama uzmanlarını eklemiştir. Pazarlama uzmanları; "birçok ürün çeşidi, alışveriş yerleri ve pazarların diğer yönleri hakkında bilgi sahibi olan, tüketicilerle tartışmalar başlatan ve tüketicilerin pazar bilgisi taleplerine cevap veren kişiler" olarak tanımlanmaktadır (Feick ve Price, 1987, s. 85). Menfaat bekleyenler, bir bedel karşılığında çevresindeki insanlara firmayı tavsiye eden kişileri (Dobele, 2002, s. 673); faydalı arkadaşlar, alışveriş yapan kişilere satın alma noktasında eşlik ederek bilgi veren ve sosyal destek veren kişileri (Kiecker ve Cowles, 2001, s. 75); minnet ödeyenler, kendi firmalarını öven firmaları etrafındakilere tavsiye eden kişileri ve ağzı kapalılar, hizmetleri ve teklifleri sessizce değerlendirdikten sonra, bu bilgileri kimseyle paylaşmayan kişileri ifade etmektedir (Dobele, 2002, s. 674). Ağızdan ağıza pazarlamada, tüketicilerin fikirlerini şekillendirmede kanaat önderleri önemli bir rol oynamaktadır (Towhidi ve Sinha, 2015, s. 1). Bu bağlamda yakın çevresindeki kişileri etkileyebilme gücü bulunan kişiler "kanaat önderleri" olarak tanımlanmaktadır. 
Dijitalleşen dünya ile birlikte geleneksel pazarlama yöntemleri dönüşüm geçirmiştir. Bu bağlamda, ağızdan ağıza pazarlamanın bir yöntemi olan e-etkileyici kişi pazarlaması, işletmeler tarafından sıkıkla kullanılan bir yöntem olarak karşımıza çıkmaktadır. E-etkileyici kişi pazarlamasının, yüz yüze gerçekleşen geleneksel ağızdan ağıza pazarlamadan ayrımasının temel nedeni, hedef kitleye ulaşması amaçlanan mesajların e-etkileyici kişiler aracılığıyla sosyal medya platformları üzerinden iletilmesidir.

E-etkileyici kişilerin, sosyal medya platformlarında bulunanları etkileme gücü bulunması sebebiyle sosyal medyanın kanaat önderleri olduğu söylenilebilmektedir. Ingilizceden gelen "influencer" kelimesi, elektronik ortamda eylemleri ile başkalarını etkileyen kişi anlamına gelmektedir. E-etkileyici kişiler itibarı, bilgisi ve pozisyonu sayesinde onu takip eden kişilerin fikirlerini ve/veya davranışlarını etkileyebilmektedir (Jahnke, 2018, s. 4). Sosyal medyanın büyümesiyle birlikte, sıradan tüketiciler daha etkili bir gruba dönüşmüştür. Internetin gücü sayesinde, bu tüketicileri etkileyen e-etkileyici kişilerin birçoğu, aynı ilgi alanlarını paylaşan insanları bir araya getirmekte ve bu sayede pazarda güçlü bir sese sahip olmaktadırlar (Booth ve Matic, 2011, s. 184).

Brown ve Hayes (2008, s. 23), e-etkileyici kişiyi; "müşterilerin satın alma kararlarını önemli derecede etkileme gücüne sahip ancak bunun için hiçbir zaman sorumlu olmayan üçüncü bir taraf" olarak tanımlamaktadır. Sosyal medyada büyük bir takipçi ağı oluşturmuş ve bu ağ içindeki insanları etkileyebilme gücüne sahip ve güvenilir olarak kabul edilen e-etkileyici kişiler (Abidin, 2016, s. 87), kendi içeriklerini (metin, ses, video vb.) yüksek ve düzenli bir frekansta yayınlayabilme ve böylelikle sosyal bir etkileşim başlatabilme niteliğine sahiptir. Bu etkileşim bloglar, Facebook, YouTube, Instagram veya Twitter gibi internet tabanlı iletişim kanalları aracılığıyla yapılmaktadır (Deges, 2018, s. 14).

Ağızdan Ağıza Pazarlama Derneği, e-etkileyici kişi pazarlamasını; ürünler hakkında konuşan ve başkalarının fikirlerini etkileme yeteneğine sahip olan önemli toplulukları ve kanaat önderlerini belirleme olarak tanımlamaktadır (Beam vd., 2013, s. 42). Bu bağlamda e-etkileyici kişi pazarlaması, ağızdan ağıza pazarlama kavramının bir uzantısı olarak sosyal bir durum üzerine odaklanmakta ve ağızdan ağıza pazarlamadan daha profesyonel bir şekilde gerçekleştirilmektedir. Bu doğrultuda e-etkileyici kişi pazarlamasının, takipçi kitlesini genişletmek ve güvenilirlik yoluyla bu kitleyi sadık müşterilere dönüştürmek isteyen markalar için yararlı bir ilişki kurma yöntemi olduğu söylenebilir (Sudha ve Sheena, 2017, s. 16).

E-etkileyici kişileri geleneksel ünlülerden (celebrity) ayıran en belirgin fark, e-etkileyici kişilerin sosyal medya platformlarında içerik üreterek takipçi ağı oluşturmasıdır. Diğer bir ifadeyle, e-etkileyici kişiler, sosyal medya platformlarında içerik üretmeden önce tanınmayan kişilerdir. Ünlüler hayranlarıyla iletişim kurmak veya kendi yaptıklarını duyurmak gibi sebeplerle sosyal medya platformlarını kullanırken (Zeren ve Gökdaglı, 2020, s. 697), e-etkileyici kişiler bu platformlarda 
içerik üreterek ünlenmek ve insanları etkileyebilmek gibi amaçlarla bu platformları kullanmaktadır (Gedik, 2020, s. 367). İşletmeler uzun yıllardır daha geniş kitlelere ulaşmak, marka imajını, güvenini ve sadakatini arttırmak gibi çeşitli sebeplerle reklamlarında belirli bir hayran kitlesine ulaşmış ünlüleri kullanmaktadır (Uyar, 2018 , s. 121, 122). Ünlü onayı (celebrity endorsement) olarak adlandırılan bu teknik, ünlüleri reklamlarda göstererek tüketicilerdeki satın alma niyetini arttırmayı amaçlamaktadır (Bhakar vd., 2015, s. 88; Spry vd., 2011, s. 883). Bu teknik geleneksel kitle iletişim araçlarında olduğu gibi dijitalleşen dünya ile birlikte ünlülerin sosyal medya hesaplarından da yapılabilmektedir. E-etkileyici kişi kullanımını ünlü onayı tekniğinden ayıran fark, e-etkileyici kişi kullanımının sadece sosyal medya platformlarında yapılmasıdır. Sosyal medyada yaptığı içeriklerle tanınan e-etkileyici kişiler kendi içeriklerine uygun markalarla iş birliği yaparak markanın ürünlerini takipçilerine tavsiye etmektedir. Zeren ve Gökdağlı (2020) yaptıkları çalışmada, Türk ünlülerin ve e-etkileyici kişilerin Instagram'daki performanslarını incelemiştir. Yapılan çalışmanın bulgularına göre, e-etkileyici kişiler Instagram'da ünlülerden daha aktifken, ünlülerin daha fazla takipçisi ve marka desteği bulunmaktadır. İşletmelerin hala geleneksel marka stratejilerini devam ettirmesi sebebiyle ünlülerin toplamda daha az gönderisi bulunmasına rağmen bir marka ile ilgili daha fazla gönderisi bulunmaktadır. Ayrıca, e-etkileyici kişilerin güvenilir olarak algılanmasını destekleyen bulgular olsa da işletmeler markalarını tanıtmak için hala geleneksel ünlüleri tercih etmektedir.

Literatürde e-etkileyici kişi pazarlaması üzerine çeşitli çalışmalar bulunmaktadır. Haenlein ve diğerleri (2020) yaptıkları çalışmada, işletmelerin e-etkileyici kişi pazarlaması yapabilmesi için en doğru platformların hangileri olduğu, e-etkileyici kişi pazarlamasının nasıl yapılması, bu konuda nelere dikkat edilmesi gerektiği ve işletmelerin doğru e-etkileyici kişileri belirlemeleri için hangi hususlara dikkat edilmesi gerektiği üzerinde durmaktadır. E-etkileyici kişi pazarlamasının yönetilmesi için işletmelere önerilerde bulunmayı amaçlayan bu çalışmada, e-etkileyici kişiler genel bir perspektiften ele alınmıştır. Breves ve diğerleri (2019) yaptıkları çalışmada, Instagram'daki e-etkileyici kişilerin algılanan güvenilirliğinin ve uzmanığının marka değerlendirmeleri ve davranışsal niyetler üzerindeki etkisini analiz etmişlerdir. Araştırmanın bulgularına göre, e-etkileyici kişiler uzmanlık ve ilgi alanlarına uygun olan markalarla iş birliği yapmalıdır. Bu durum, e-etkileyici kişilerin güvenilirliğini etkilemenin yanı sıra marka tutumu ve davranışsal niyetler üzerinde de doğrudan bir etkiye sahiptir. Arora ve diğerlerinin (2019) yaptıkları çalışma, Facebook, Twitter ve Instagram gibi popüler sosyal medya platformlarında e-etkileyici kişi endeksini ölçmek için bir teknik önermektedir. Çalışmanın bulgularına göre, e-etkileyici kişilerin belirlenmesinde etkileşim, sosyal yardım, duyarlılık ve büyüme önemli bir rol oynamaktadır.

Yapılan araştırmalarda; ünlüler (Djafarova ve Rushworth, 2017), marka topluluğu üyeleri (Kim vd., 2014) ve blog yazarları gibi e-etkileyici kişi kullanımının, tüketiciler üzerinde pozitif marka tutumu oluşmasında ve satın alma niyetlerinin artmasında önemli bir rol oynadığı saptanmıştır. Sosyal medya temelli e-etkileyici 
kişi pazarlamasının tüketicilerin büyük bir kısmına daha kısa bir zamanda ulaşması ve geleneksel reklam kampanyalarına göre daha düşük bir maliyetle yapılabilmesi bu yöntemi oldukça popüler kılmaktadır (Evans vd., 2017, s. 4). Ayrıca, tüketicilerin tanıtılan ürün veya e-etkileyici kişi hakkında yorum yapması, içeriği etkilemekte ve bu nedenle tüketicinin içeriği benimsemesi kolaylaşmaktadır (Mert, 2018, s. 1323).

E-etkileyici kişi pazarlaması farklı sosyal medya mecralarında yapılmaktadır. Bu çalışmada ise Instagram mecrası seçilmiştir. Çünkü Amerika'daki e-etkileyici kişi pazarlaması platformu olan Linqia'nın (2017, s. 8) yayınladığı "The State Of Influencer Marketing 2018" rapora göre, 2018'de e-etkileyici kişi pazarlamasının en çok yapıldığı mecra olarak \%92 ile Instagram belirlenmiştir.

Instagram'da e-etkileyici kişiler, fotoğraf ve video paylaşarak, etiketler kullanarak ve takipçileriyle etkileşime girerek büyük hayran kitleleri oluşturmaktadırlar. Instagram'daki e-etkileyici kişileri ürünlerini pazarlamak için kullanmak isteyen markalar, niş ilgi alanları hedef kitlesiyle aynı olan kişileri seçmektedir. Bu doğrultuda, e-etkileyici kişilerin marka ile ilgili gönderileri takipçileriyle paylaşmasıyla marka ve e-etkileyici kişiler arasında yararlı bir ilişki kurulmaktadır. Markalar, e-etkileyici kişilerle sponsorlu içeriklerin, gönderilerin ve ürün yerleştirmelerin paylaşılması gibi çeşitli şekilde iş birliği yapmaktadır. Örneğin, e-etkileyici kişiler Instagram hesaplarında iş birliği yaptıkları markanın ürününü deneyimleyerek takipçileriyle paylaşmaktadır (Evans vd., 2017, s. 139).

E-etkileyici kişilerin herhangi bir marka ile iş birliği yaptıklarında bu ticari ilişkiyi gönderilerinde belirtmesi gerekmektedir. Bu bağlamda Instagram, şeffaflığın sağlanması adına standartlaştırılmış bir açıklama ("[marka] ile ücretli ortaklık") getirmiştir. Boerman (2020) yaptığı çalışma ile, bu açıklamanın reklamın tanınırlığını etkili bir şekilde arttırıp arttırmadığını ve bunun sonucunda tüketicilerin mesaja, e-etkileyici kişiye ve markaya yönelik tepkilerinin nasıl etkilendiğini incelemiştir. Ayrıca Boerman, bu açıklamanın etkilerini mikro (10 bin takipçiden az) ve orta (10 bin ve 1 milyon arası takipçi) e-etkileyici kişiler arasında karşılaştırmıştır. Araştırma bulgularına göre, e-etkileyici kişiler herhangi bir ticari ilişkiyi takipçileri ile paylaştıklarında, reklamın tanınmasını etkili bir şekilde arttırmaktadır. Saptanan bir diğer bulgu ise, bu açıklamanın markanın hatırlanmasını ve reklamı tanıma yoluyla gönderi ile etkileşim kurma niyetini olumlu yönde etkilediği yönündedir. Ancak bu çalışmanın bulgularına göre, e-etkileyici kişi türünün (mikro ve orta) açıklamanın etkisini ve tüketicilerin mesaja, e-etkileyici kişiye veya markaya yönelik tepkilerini etkilemediği sonucuna ulaşılmıştır. Yaptıkları çalışmada e-etkileyici kişi pazarlamasını ünlü onayının modern bir biçimi şeklinde ele alan Lee ve Kim (2020) ise, ünlü e-etkileyici kişilerin Instagram'daki ürün tanıtımı gönderilerinin etkinliğini incelemiştir. Çalışmanın bulguları, ünlü e-etkileyici kişilerin gönderilerinde açık ("sponsorlu" ve "reklam") veya örtük bir ticari açıklamanın ("sp" ve"ad") reklamların tanınma düzeyini etkilemediği göstermektedir. Ilaveten, ünlü e-etkileyici kişilerin güvenilirliğinin algılanan mesaj güvenilirliğini, reklama yönelik tutumu, satın alma niyetini ve elektronik ağızdan ağıza pazarlama niyetini önemli ölçüde etkilemediği 
saptanmıştır. Çünkü tüketiciler Instagram'da ünlüler tarafından tanıtılan ürünlerin kendi görüşlerini yansıtmaktan ziyade ücreti ödenmiş bir yorum olduğuna inanmaktadırlar. Çalışmanın bir diğer bulgusuna göre ise, insanlar yüksek güvenilirliği olan markaların Instagram gönderilerine düşük güvenilirliği olan markalara göre daha olumlu bir tutum sergilemektedir.

Bu çalışmada, e-etkileyici kişi pazarlaması yaparken, markaların kampanyalarında yer almasını istediği e-etkileyici kişiler, takipçi tabanına bağlı olarak farklı kategorilere ayrılmıştır. Çeşitli çalışmalara (Jahnke, 2018; Neil, 2018; Sandoval, 2018; Gottbrecht, 2016; Mavrck, 2016) dayanarak oluşturulan bu kategorilere göre sosyal medya platformlarında 500 ve 10 bin arasında takipçi kitlesi bulunan kişiler "Mikro E-Etkileyici Kişi"; 10 bin ve 1 milyon arasında takipçi kitlesi bulunan kişiler "Makro E-Etkileyici Kişi" ve 1 milyon ve üzerinde takipçisi bulunan kişiler "Mega E-Etkileyici Kişi" olarak belirlenmiştir.

Markalar, kampanyalarında yer almasını istedikleri e-etkileyici kişiyi, "E-etkileyici Kişi Pazarlamasının 3R"si olarak bilinen erişim (reach), alaka düzeyi (relevance) ve rezonans'ı (resonance) dikkate alarak saptamaktadır. Bu bağlamdan yola çıkarak, ünlü bir pazarlama ajansı olan Mavrck (2016)'in yayınlamış olduğu istatistiklere göre, mega e-etkileyici kişilerin gönderilerine \%2 ile \%5 arasında katılım gerçekleştiği görülmektedir. Alaka düzeyleri irdelendiğinde ise, konuyla ilgili alaka düzeyleri yüksek iken markayla ilgili alaka düzeylerinin düşük olduğu belirtilmektedir. Ayrıca mega e-etkileyici kişilerin rezonansları incelendiğinde, takipçileriyle etkileşim düzeylerinin düşük olduğu gözlemlenmektedir. Makro e-etkileyici kişilerin erişim oranlarına bakıldığı zaman ise gönderilerine \%5 ile \%25 arasında katılım gerçekleştiği görülmektedir. Makro e-etkileyici kişilerde mega e-etkileyici kişiler gibi konuyla ilgili alaka düzeyleri yüksek iken markayla ilgili alaka düzeyleri düşüktür. Ayrıca bu istatistiklere göre makro e-etkileyici kişilerin rezonansları incelendiğinde, takipçileriyle etkileşim oranlarının orta olduğu gözlemlenmektedir.

Mikro e-etkileyici kişiler genellikle mevcut tüketicilerden veya çalışanlardan oluşmaktadır. Mavrck'e (2016) göre, bu kişiler en düşük erişime sahip olmasına rağmen, takipçileriyle kişisel düzeyde bağlantı kurabildikleri için gönderi başına en yüksek katılım oranına (\%25 ile \%50) sahip kişilerdir. Mikro e-etkileyici kişilerin konuyla ilgili alaka düzeyleri düşük, markayla ilgili alaka düzeyleri yüksektir. Bir marka ile olan kişisel deneyimleri ve sosyal ağlarında takipçileriyle arasındaki bağın güçlülüğü sayesinde, e-etkileyici kişi pazarlaması türleri arasındaki en yüksek marka alaka düzeyine ve rezonansına sahip kişilerden oluşmaktadırlar (Gottbrecht, 2016).

Sosyal medya platformlarında bireyler, bilgiyi birbirleriyle paylaşarak etkileşimde bulunmakta ve bu etki ağının bir parçası olarak aynı zamanda mikro e-etkileyici kişilerle de çift yönlü bir etkileşime girmektedirler. Bu etkileşim sayesinde bilgi ve tecrübeler sosyal medya platformlarında yayılarak bilgi paylaşımını yaratmaktadır. Mikro e-etkileyici kişilerin yaydıkları mesajlar, sosyal ağlarında yer alan takipçilerine iletilmektedir. Daha sonra bu mesajlar takipçilerinden onların 
takipçilerine iletilerek çok yönlü ve çok aşamalı bir biçimde markanın belirlediği hedef kitleye erişmektedir (Brown ve Fiorella, 2013, s. 144; Avcılar ve Açar, 2017, s. 10). Mikro e-etkileyici kişiler; geleneksel ünlülerden farklı olarak kendi alanında uzmanlaşmış; bilgili, otantik, orijinal ve ürün hakkında verdiği öneriler ile güvenilir bir kaynak olarak algılanan kişilerdir (Brown ve Fiorella, 2013, s. 119; Öztürk ve Şener, 2018, s. 388).

Tüm e-etkileyici kişiler arasındaki en büyük grup mikro e-etkileyici kişilerdir. Aynı zamanda bu kişiler, sadık takipçiler elde etmede etkili kişiler olarak kabul edilmektedirler. Çünkü mikro e-etkileyici kişilerin takipçi tabanı az olduğu için onlarla birebir bağlantı kurabilmektedirler. Bu etkileşim sayesinde bu kişilerin takipçileri kendilerini değerli hissetmekte ve gönderilerine daha fazla ilgi gösterme eğilimi göstermektedir (Jahnke, 2018, s. 226; Neil, 2018). Amerika'da ünlü bir e-etkileyici kişi pazarlaması ajansı olan Markerly'in (2016) yaptığı bir çalışmada, 800 binden fazla Instagram kullanıcısının beş milyon Instagram gönderisi analiz edilmiştir. Analizin ana bulgusu; e-etkileyici kişilerin takipçi sayısı arttıkça, takipçilerle olan etkileşim oranının (beğeniler ve yorumlar) azaldığıdır. Bu çalışmaya göre, Instagram'da 1000'den az takipçisi olan kişiler, gönderilerinde ortalama olarak \%8 oranında bir başarı elde etmektedir. 1000 ile 10 bin arasında takipçisi olan kişilerde bu oran \% 4 iken, 1 milyondan fazla takipçisi olan kişilerde \% 1,6'ya düştüğü görülmektedir. Bu nedenle, e-etkileyici kişi pazarlamasında, markalar mikro e-etkileyici kişilerle iş birliği yapma eğilimindedir.

Markaların mikro e-etkileyici kişileri iletişim kampanyalarında kullanmak istemelerindeki en önemli faktör, bu kişilerin takipçileriyle olan etkileşim oranlarının yüksek olmasıdır. Diğer faktörler aşağıda belirtildiği gibi sıralanabilmektedir:

- Markaların mikro e-etkileyici kişilerle iş birliği yapmalarının bir diğer önemli sebebi, mega ve makro e-etkileyici kişilere göre daha uygun maliyetli olmasıdır (Gallegos, 2018). Influence.co (2018) tarafından yayınlanan bir rapora göre; mikro e-etkileyici kişiler, Instagram'da yayınladıkları gönderi başına yaklaşık 93 ile 137 dolar arasında bir ücret alırken, makro veya mega e-etkileyiciler gönderi başına 133 ile 1,405 dolar arasında bir ücret almaktadırlar.

- Mikro e-etkileyici kişiler, tüketicilerin satın alma kararları üzerinde mega ve makro e-etkileyici kişilerden daha fazla etkilidir (Brown ve Fiorella, 2013, s. 90). Çünkü mikro e-etkileyici kişiler, tüketicilerin çevresindeki kişilerden veya kendilerine yakın hissettikleri kişilerden oluşmaktadır. Bu nedenle, bu kişilerin öneri veya yorumlarının tüketicilerin bir ürünü satın almaları sırasında etkisinin olduğunu söylenebilmektedir (Brown ve Fiorella, 2013, s. 83).

- Mikro e-etkileyici kişiler tüketiciler tarafından güvenilir ve özgün kişiler olarak görülmektedirler. Bu kişilerin takipçileri hayranlık duygusundan ziyade güven duydukları için takip etmektedirler (Adams, 2016). 
- Mikro e-etkileyici kişiler belirli bir alanda uzmanlaşmışlardır. Bu kişilerin takipçi kitlesi spesifiktir. Belirli mikro e-etkileyici kişileri takip eden insanlar genellikle ortak şeylere (yaş, ilgi alanları, cinsiyet vb.) sahiptir. Bu durum markalara, takipçilerini daha kesin hedefleme ve bu hedef kitleye göre marka mesajını yayma imkânı tanımaktadır (Marwick, 2013, s. 114; Jahnke, 2018, s. 230; Barker, 2017; Mediakix, 2017).

Mikro e-etkileyici kişi kullanımının birçok avantajı olduğu gibi bazı dezavantajları da bulunmaktadır. Mediakix (2017), bu dezavantajları aşağıda belirtildiği gibi sıralamaktadır:

- Düşük erişim: Mikro e-etkileyici kişiler, yüksek etkileşim oranına sahip olmalarına rağmen daha az insana ulaşabilmektedirler. Mega ve makro e-etkileyici kişiler, aynı anda birçok insana ulaşabiliyorken; aynı oranda kişiye ulaşabilmek için çok sayıda mikro e-etkileyici kişi ile çalışmak gerekmektedir. Bu nedenle markalar, mikro, makro veya mega e-etkileyici kişiler etrafında kampanyalar tasarlarken, maruz kalma, farkındalık, katılım ve dönüşüm hedeflerini göz önünde bulundurmalıdır.

- Daha az gerçek katılım potansiyeli: Mikro e-etkileyici kişilerin niş topluluklara hitap etmesi, her zaman daha yüksek katılım olacağı anlamını taşımamaktadır. Aktif ve katıımcı olan bu niş topluluğu teşvik etmek için mikro e-etkileyici kişilerin çok fazla çalışması, sahte takipçiler satın almaması ve özel içerikler üretmesi gerekmektedir.

- Tüketicilere ulaşmak için daha fazla çalışma: Her mikro e-etkileyici kişinin farkı intiyacı ve iletişim gereksinimi olduğu için bu kişilerle çalışmak çoğu zaman daha fazla iş yaratmaktadır. Çünkü yakın ilgi ve deneyim yararı gerektiren birçok değişken ve ayrıntı bulunmaktadır. Açık, tutarlı ve doğru marka mesajların iletilmesi kampanyanın başarııı için büyük önem taşımaktadır.

\section{Marka Tutumu Kavramı}

Tutum, "belirli bir nesneye karşı tutarlı bir şekilde olumlu veya olumsuz bir şekilde davranılması için öğrenilmiş bir eğilim" şeklinde tanımlanmaktadır. Tüketici davranışı bağlamında bir "nesne"; tüketimin diğer birçok yönünün yanı sıra bir ürün, marka, fiyat, paket, reklam, tanıtım ortamı veya ürünü satan perakendeci olabilmektedir. Marka tutumları, tutum nesnesinin olumlu ya da olumsuz değerlendirmelerini yansıtmakta ve tüketicileri belirli ürünleri ya da markaları alması ya da almaması yönünde motive etmektedir. (Schiffman ve Wisenblit, 2015, s. 172). Marka tutumunun tüketicilerin satın alma kararlarını etkiliyor olması, marka tutumunun önemini göstermektedir.

Mitchell ve Olson (1981, s. 318), markaya yönelik tutumu; "bireyin markaya yönelik olan içsel değerlendirmesi" şeklinde tanımlamaktadır. Marka tutum- 
ları, bir ürünün intiyaçları karşılama, kendi imajını geliştirme, kültürel değerlere cevap verme ve inançlara ve deneyimlere anlam verme yeteneklerine ilişkin algıların yanı sıra ürün alımlarını da etkilemektedir. Bir markaya yönelik olumlu tutumu olan tüketiciler, olumlu tutumu olmayan tüketicilerden farklı davranmaktadır. Ayrıca, olumsuz tutumları değiştirmenin daha zor olduğu söylenebilmektedir (Reisinger, 2009, s. 305). Marka tutumları; tüketicilerin düşüncelerini yönlendirmekte, duygularını ve davranışlarını etkilemektedir. Tüketiciler oluşturdukları tutumlar doğrultusunda, hangi reklamı izleyeceklerine, nereden alışveriş yapacaklarına ve hangi markayı satın alacaklarına karar vermektedir. Bu durum, pazarlamacılar açısından olumlu marka tutumu oluşturmanın önemini göstermektedir.

Üç bileşenli tutum modeline göre marka tutumu; "bilişsel", "duygusal" ve "davranışsal" olarak üç tane ana bileşenden oluşmaktadır (Mothersbaugh ve Hawkins, 2016, s. 385). Bilişsel bileşen, tüketicinin bir nesne hakkındaki düşüncelerinden oluşmaktadır (Mothersbaugh ve Hawkins, 2016, s. 384; Solomon, 2017, s. 286; Ajzen, 2005, s. 4). Diğer bir ifadeyle, bilişsel bileşen, tüketicilerin tutum nesnesiyle doğrudan deneyimlediği ya da çeşitli kaynaklardan edindiği nesnenin niteliklerinin bilgilerinden ve algılarından oluşmaktadır (Schiffman ve Wisenblit, 2015, s. 176). Bilişsel bileşen, potansiyel satın alma motivasyonları için önemlidir. Bilişsel sürecin sonucu, ürün özelliklerinin anlamsal içeriğini kapsamaktadır (Silva ve Alw, 2006, s. 294). Grimm'in (2005) yapmış olduğu bir çalışmanın bulgularına göre, bilişsel marka özelliklerinin marka tercihleri üzerinde önemli bir etkiye sahip olduğu söylenebilmektedir. Marka tutumunun duygusal bileşeni, tüketicilerin belirli bir markaya yönelik duygularını ve hislerini ifade etmektedir (Peter ve Olson, 2009, s. 39; Mothersbaugh ve Hawkins, 2016, s. 387; Solomon, 2017, s. 286). Marka tutumunun davranışsal bileşeni ise, tüketicilerin tutum nesnesine belirli bir şekilde yanıt verme eğilimini ve davranışsal amaçları ifade etmektedir. Gerçek davranışlar, davranışın ortaya çıktığı durum tarafından değiştirildiği için bu amaçları yansıtmaktadır (Mothersbaugh ve Hawkins, 2016, s. 388-390; Solomon, 2017, s. 286; Silva ve Alw, 2006, s. 295).

Markalar, yukarıda belirtilen üç tutum bileşeni ile uyumlu çalışmalar gerçekleştirerek, tüketicilerin markaya yönelik olumlu bir tutum oluşturmasını veya var olan tutumun olumlu yönde değiştirilmesini amaçlamaktadır. Bu doğrultuda, markaların bilişsel, duygusal ve davranış bileşenleri göz önünde bulundurarak tüketicileri ikna edici bir çalışma gerçekleştirmesi gerekmektedir. Mikro e-etkileyici kişiler bir markayı veya ürünü takipçileri ile paylaşırken onlar üzerinde olumlu bir marka tutumu oluşturmayı amaçlamaktadır. Güvenilir bir kaynak olarak kabul edilen mikro e-etkileyici kişiler, bu üç bileşen üzerinden ikna edici bir iletişim gerçekleştirmektedir.

\section{Araştırmanın Amacı, Türü ve Hipotezleri}

Günümüzde internet teknolojilerinin ilerlemesi, reklam mesajlarının hedef kitleye aktarılma yöntemlerini değiştirmiştir. Bu reklam mesajlarının aktarılmasında geleneksel kitle iletişim araçlarının kullanımı yerini daha çok bireylere hem tü- 
ketici hem de üretici (prosumer) (Fuchs, 2016, s. 51) olma imkânı tanıyan sosyal medya platformlarına bırakmıştır. Sosyal medyanın kanaat önderleri konumundaki e-etkileyici kişiler, deneyimledikleri ürünleri takipçileriyle paylaşarak onları tanıttıkları bu ürünleri kullanmaya teşvik etmektedirler. Karşılaştıkları tüm reklam mesajlarını değerlendirecek zamanı bulunmayan tüketiciler kendi ilgi alanlarına göre takip ettikleri ve kendileri ile özdeşleştirdikleri bu kişilerden gelen tavsiyeleri samimi bulmaktadırlar. Özellikle sosyal medya platformlarında mikro düzeyde takipçisi bulunan e-etkileyici kişilerin takipçileriyle birebir iletişime girebilmesi tüketicilerin bu kişilere karşı güven duymasını sağlayabilmektedir. Farklı yönlerden benzer özelliklere sahip spesifik grupları amaçlar doğrultusunda belirleme, hedef kitleye, beklentilerini karşılayacak mesajlarla ulaşarak marka tutumu yaratmak açısından önem taşımaktadır. Bu doğrultuda, tüketicilerin Instagram'daki iletişim kampanyalarında mikro e-etkileyici kişi kullanan markalara yönelik tutumları ile demografik durumları, günlük Instagram kullanma sıklıkları, Instagram'da takip ettikleri mikro e-etkileyici kişi sayısı, mikro e-etkileyici kişileri güvenilir bulma durumları ve mikro e-etkileyici kişilerin önerdikleri bir ürünü satın alma durumlarının anlamlı bir biçimde farklılaşıp farklılaşmadığının incelenmesi bu araştırmanın ana amacını oluşturmaktadır. Araştırma amacının gerçekleşmesi için yapılan bu çalışma, istatistiksel analiz uygulanacak rakamları elde ederek objektif sonuçlar saptamak için nicel araştırma kapsamındadır. Bu çalışmada saptanan bulgular, mikro e-etkileyici kişi kullanan veya kullanmayı planlayan markaların, hedef kitlelerinin çeşitli özellikleri doğrultusunda markaya yönelik olan tutumlarını anlamaları ve bu doğrultuda stratejiler belirlemeleri açısından yol gösterici olacağından önem taşımaktadır. Ayrıca literatürde mikro e-etkileyici kişiler üzerine yapılan çalışmaların azığı nedeniyle bu çalışmanın literatüre katkı sağlayacağının düşünülmesi araştırmanın önem taşıyan bir diğer yönüdür. Çalışma zaman ve mali kısıtlarından dolayı sadece İstanbul ilindeki Instagram kullanıcılarından elde edilen verilerle sınırlıdır. Çalışmanın sonucunda elde edilen bulgular Türkiye geneline yansıtılamamaktadır. Ancak bu çalışmanın daha kapsamlı nicel çalışmalara kaynak olması umulmaktadır.

Bu araştırma tanımsal araştırma perspektifi göz önüne alınarak tasarlanmıştır. Tanımsal araştırmaların nihai amacı bir örneklem veya olgunun nitelikleri ortaya çıkarmaktır (Gegez, 2015, s. 48). Instagram'daki e-etkileyici kişi kullanımına yönelik yapılan çalışmalar (Veirman vd., 2017; Evans vd., 2017; Avcılar ve Açar, 2017) ve tüketicilerin e-etkileyici kişilerin tanıttıkları markalara karşı olan tutum araştırmaları (Grafström vd., 2018; Veirman vd., 2017; Djafarova ve Rushworth, 2017) bağlamında araştırmada test edilmek üzere hipotezler tasarlanmıştır.

Araştırmanın test etmeyi amaçladığı hipotezler şöyledir:

H1: Mikro e-etkileyici kişi kullanımının marka tutumuna yansıması ile tüketicilerin demografik durumları arasında anlamlı bir farklıık vardır.

H1a: Mikro e-etkileyici kişi kullanımının marka tutumuna yansıması ile tüketicilerin ailelerinin aylık gelir durumları arasında anlamlı bir farklılık vardır. 
H1b: Mikro e-etkileyici kişi kullanımının marka tutumuna yansıması ile tüketicilerin algıladıkları gelir durumları arasında anlamlı bir farkılık vardır.

H1c: Mikro e-etkileyici kişi kullanımının marka tutumuna yansıması ile tüketicilerin aylık gelir durumları arasında anlamlı bir farklııık vardır.

H1d: Mikro e-etkileyici kişi kullanımının marka tutumuna yansıması ile tüketicilerin yaşları arasında anlamlı bir farklılık vardır.

H1e: Mikro e-etkileyici kişi kullanımının marka tutumuna yansıması ile tüketicilerin cinsiyetleri arasında anlamlı bir farklılık vardır.

H1f: Mikro e-etkileyici kişi kullanımının marka tutumuna yansıması ile tüketicilerin medeni durumları arasında anlamlı bir farklılık vardır.

H1g: Mikro e-etkileyici kişi kullanımının marka tutumuna yansıması ile tüketicilerin çalışma durumları arasında anlamlı bir farklılık vardır.

H2: Mikro e-etkileyici kişi kullanımının marka tutumuna yansıması ile tüketicilerin günlük Instagram kullanma sıklı̆ı arasında anlamlı bir farklılık vardır.

H3: Mikro e-etkileyici kişi kullanımının marka tutumuna yansıması ile tüketicilerin Instagram'da takip ettiği mikro e-etkileyici kişi sayısı arasında anlamlı bir farklılık vardır.

H4: Mikro e-etkileyici kişi kullanımının marka tutumuna yansıması ile tüketicilerin mikro e-etkileyici kişileri güvenli bulmaları arasında anlamlı bir farklılık vardır.

H5: Mikro e-etkileyici kişi kullanımının marka tutumuna yansıması ile tüketicilerin mikro e-etkileyici kişi tarafından önerilen ürünü almaları arasında anlamlı bir farklıık vardır.

\section{Araştırma Metodolojisi}

\section{Ana Kütle ve Örnek Kütlenin Seçimi}

E-etkileyici kişi pazarlaması, bir sosyal medya platformu olan Instagram mecrası üzerinden markalar tarafından sıklıkla kullanılmaktadır. Bu doğrultuda çaıışmanın ana kütlesini Instagram hesabı bulunan tüketiciler oluşturmaktadır. Piyasa ve kamuoyu araştırma enstitüleri tarafından toplanan verileri ve ekonomik sektörden elde edilen verileri istatistiksel olarak sunan Statista (2019) tarafından Nisan 2019 tarihinde hazırlanan "Dünya Genelindeki Instagram Kullanıcılarının Yaş Gruplarına Göre Dağılımı" başlı̆̆ı altındaki istatistiklere göre; "Instagram Kullanıcıları"nın "\%31'ini" "18-24 yaş" ve "\%32'sini" "25-34 yaş" grubu oluşturmaktadır. Bu nedenle, yapılan çalışmada anket katıımcıları 18-34 yaş grubu olarak seçilmiştir. Pazarlama araştırmaları açısından "problem çözümüne yönelik yapılan araştırmalar" da tipik örnek kütlesi "300 ile 500" kişi aralığında bulunmalıdır (Naresh ve Birks, 2000, s. 351). Bu nedenle araştırmada "350 kişilik bir örneklem" oranına ulaşmak amaçlanmıştır. Bu araştırmada anket katııımcıları zaman ve ma- 
liyet kısıtı nedeniyle "uygun örnekleme" yöntemiyle belirlenmiştir. Uygun örnekleme yönteminde, örneklem, araştırmacının çevresinde yer alan tanıdık çevreden oluşmaktadır (Yıldırım ve Şimşek, 2016, s. 54). Bu bağlamda araştırmadaki anket katılımcıları "Marmara Üniversitesi llletişim Fakültesi'nde" eğitim görmekte olan öğrencilerinden oluşmaktadır. Araştırmanın örneklemi uygun örnekleme yöntemi ile belirlenmiş Instagram kullanııılarından oluşmaktadır. Çalışma için, 2019 yıının Mayıs ayında Marmara Üniversitesi İletişim Fakültesi öğrencilerinden oluşan toplam 347 kişiden veri elde edilmiştir.

\section{Veri Toplama Yöntemi}

Araştırma kapsamında veriler "anket yöntemi" ile toplanmıştır. İstanbul'da ikamet eden, Instagram kullanan veya kullanmış olan, lisans ve daha üstü eğitim alan ve farklı sosyo-ekonomik niteliklere sahip kullanıcıların ana kütlesini oluşturduğu bu çalışma için yüz yüze anket toplama yöntemi kullanılmıştır (Gegez, 2015, s. 112).

\section{Anket Sorularının Hazırlanması, Test Edilmesi ve Araştırmada Kullanılan Ölçekler}

Araştırma kapsamında kullanılan anket "üç bölüm"e ayrılmaktadır. Anketin ilk bölümünde, katılımcılara yönelik olarak demografik sorular ve kişisel değerlendirmelerini etkileyebilecek çeşitli öğelerle ilgili sorular yer almaktadır. Ankette yer alan ikinci bölümde, ankete katılan kişilerin "Instagram'da" takip ettikleri mikro e-etkileyici kişilere karşı olan tutumunu ölçmeye yönelik sorular bulunmaktadır. Anket formunun son kısmındaysa katıımcıların mikro e-etkileyici kişi kullanımının markaya olan tutumlarına yansımasını tespit etmeye yönelik ölçek yer almaktadır.

Araştırmada yer alan ölçek, anket katılımcılarının mikro e-etkileyici kişi kullanımının marka tutumlarına yansımalarını ölçmek için Bruner ve Kumar (2000), Baker ve Churchill (1977), Batra ve Ahtola (1990), Spears ve Singh (2004)'in ölçeklerinden uyarlanmıştır. Ölçek mikro e-etkileyici kişi kullanımının marka tutumuna etkisini 5 boyutta incelemiştir. Anket, katıımcıların 5'li likert üzerinden değerlendirme yapmasını sağlamaktadır.

\section{Mikro E-Etkileyici Kişi Kullanımının Marka Tutumuna Yansımasına Yönelik Ölçeğin Güvenilirlik Analizi}

Mikro e-etkileyici kişi kullanımının marka tutumuna etkisini belirlemeye yönelik ölçeğin güvenilirliğini "Cronbach's Alpha" katsayısı hesaplanarak test edilmiş ve ilgili değer 0,951 olarak gözlenmiştir. Ölçeğin geçerliliğini ortaya koyabilmek aşamasında ise "faktör analizi"nden yararlanılmıştır. Faktör analizi kapsamında döndürme yöntemi olarak "Varimax" tercih edilmiş ve faktör analizi sonucunda ölçek dört faktör altında toplanmıştır. Ölçeğin "açıklanan varyans" oranı \% 70.165, "Kaiser-Meyer-Olkin (KMO)" değeri 0.941 (>0.60), "Bartlett testi" ne- 
ticesi ise $0.000(<0.05)$ olarak belirlenmiştir. Tablo 1 'de bahsi geçen analizle ilgili veriler bulunmaktadır.

Tablo 1. Mikro E-Etkileyici Kişi Kullanımının Marka Tutumuna Yansımasını Belirlemeye Yönelik Ölçeği Faktör Yapısı

\begin{tabular}{|c|c|}
\hline Boyut & $\begin{array}{l}\text { Faktör } \\
\text { Yükü }\end{array}$ \\
\hline \multicolumn{2}{|l|}{ Duygusal Boyutu (Özdeğer=10,779; Açılanan Varyans=30,303; Alpha=0,938) } \\
\hline Milkro e-etkileyici kişilerle karģllkkh diyaloga girebilmek markaya güven duymamda etkilidir. & 0,790 \\
\hline Milko e-etkileyici kişilerin doğăl davranması markayı sermemde etkilidir. & 0,784 \\
\hline Milkro e-etkileyici kişilerin güvenilir olması markayı sevmeme neden olmaktadrr. & 0,735 \\
\hline Milko e-etkileyici kişilere karg̣ı kendimi yakm hissetmem markayı tercih etmemde etkilidir. & 0,725 \\
\hline Milkro e-etkileyici kişilerin doğal davranması ve arkadaş gibi hisgettirmesi markayı tercih etmemde etkilidir. & 0,722 \\
\hline Milkro e-etkileyici kişiyle kendimi özdeşleģtirmem markaya karg̣ı ilggili olmama sebep olmaktadır. & 0,715 \\
\hline Mikro e-etkileyici kişilerin doğăl içeriklerle bir markayı tanıtması markaya gũven duymada ikna edici bir unsurdur. & 0,706 \\
\hline Milkro e-etkileyici kişilerle karg̣ıllkhı diyaloga girebilmek markaya karģ̣ olumlu duygulara sahip olmamı sağlamaktadır. & 0,703 \\
\hline Milko e-etkileyici kişilerin ulag̣ılabilir olması markayı tercih etmemde etkilidir. & 0,687 \\
\hline Milkro e-etkileyici kişiyle kendimi özdeşleştimem markayı satın almamda etkilidir. & 0,581 \\
\hline $\begin{array}{l}\text { Milro e-etkileyici kị̧ilerin kullanıp memnun kaldikları ürünleri (moda, güzellik, gezi, spor ve benzeri ürünler) } \\
\text { paylaşması markaya karşı heyecan duymamda etkilidir. }\end{array}$ & 0,520 \\
\hline \multicolumn{2}{|l|}{ Bilisssel Boyutu (Ōzdeǧer $=1,690 ;$ Açıllanan Varyans=17,257; Alpha=0,910) } \\
\hline Milaro e-etkileyici kiģilerin tavsiye ettikleri markaları daha kullamıģlı buluyorum. & 0,852 \\
\hline Milaro e-etkileyici kişilerin tavsiye ettikleri markaları daha dayanıklı buluyorum. & 0,800 \\
\hline Milro e-etkileyici kişilerin tavsiye ettikleri markalarm performanslarmı daha iyi buluyorum. & 0,779 \\
\hline Milko e-etkileyici kişilerin tavsiye ettikleri markaları daha ekonomik buluyorum. & 0,769 \\
\hline \multicolumn{2}{|l|}{ Davramışsal Boyutu (Özdeğer=1,174; Ac̣ılanan Varyans=12,782; Alpha=0,812) } \\
\hline Yalnuzca mikro e-etkileyici kigilerin tanuttkları markaları satm alınm. & 0,829 \\
\hline Milkro e-etkileyici kişilerin kullanıp memnun kaldıkları ürünleri paylaşmassı sonucunda o markayı satın alırım. & 0,640 \\
\hline Milkro e-etkileyici kişilerin tanıttıkları markalan başkalanna öneririm. & 0,616 \\
\hline $\begin{array}{l}\text { Milaro e-etkileyici kişilerin kullanıp memnun kaldikları ürünleri (moda, güzellik, gezi, spor ve benzeri ürünler) } \\
\text { paylaşması markayı satı almamda etkilidir. }\end{array}$ & 0,564 \\
\hline \multicolumn{2}{|l|}{ Farkandalık Boyutu (Ö̈ndeğer $=1,091 ;$ Açlklanan Varyans $=9,823 ;$ Alpha $=0,900$ ) } \\
\hline Milaro e-etkileyici kişilerin düzenli olarak markayla ilg̣ili gōnderi paylag̣ması markayı tanımama yardımcı olur. & 0,877 \\
\hline Milkro e-etkileyici kişilerin düzenli olarak markayla ilgili gönderi paylag̣ması markayı hatulamama yardumcı olur. & 0,861 \\
\hline
\end{tabular}

\section{Araştırmada Kullanılan Verilerin İstatistiksel Analizi}

Mikro e-etkileyici kişi kullanımının marka tutumundaki rolünün belirlenmesi üzerine yapılan araştırmada verilerin analizi aşamasında "SPSS v.22" ("Statisti- 
cal Package for Social Sciences") programı kullanılmıştır. Bu verilerin incelenme aşamasında "sayı", "yüzde", "ortalama", "standart sapma" gibi unsurlardan yararlanılmıştır.

Ölçek boyutları 1 ile 5 puan aralığında ölçülmektedir. Bu bağlamda dağılım aralığını hesap edebilmek için "Dağıım aralığı=En büyük değer- En küçük değer/ Derece" formülünden yararlanıımıştır. Bahsedilen dağılım aralığı "4 puanlık" genişlikte bulunmakta ve bu genişlik ise 5 eşit genişliğe bölünmektedir. Araştırmada elde edilen veriler aşağıda belirlenen sınır değerler kapsamında yorumlanmıştır (Sümbüloğlu, 1993, s. 9).

$$
\begin{aligned}
& \text {. "Çok düşük=1.00- 1.79" } \\
& \text {. "Düşük=1.80- 2.59" } \\
& \text {. "Orta=2.60- 3.39" } \\
& \text {. "Yüksek=3.40-4.19" } \\
& \text {. "Çok yüksek=4.20-5.00" }
\end{aligned}
$$

İki tane bağımsız grubun ortalama farkının tespit edilmesi aşamasında "Bağımsız Örneklem T-Testi", en az üç grubun bir sayısal değişken ile karşılaştırılmasının tespit edilmesi aşamasında ise "Tek Yönlü Varyans Analizi (Anova)" kullanılmıştır. Eğer yapılan "Anova Testi" neticesinde grupların arasında farklılık tespit edildiyse, hangi gruplar arasında farklılık olduğunu belirleme aşamasında Posthoc analizlerinden "Scheffe Testi" den yararlanılmıştır. Edinilen sonuçlar "\%95 güven aralığı" ve "\%5 anlamlılık düzeyi" ile değerlendirilmiştir.

\section{Bulgular ve Değerlendirme}

Çalışmanın bu kısmında, katılımcılardan anket yardımıyla edinilen veriler çözümlenmiştir. Bu doğrultuda, edinilen sonuçlar üzerinden söz konusu araştırmayla alakalı açıklama ile yorumlar gerçekleştirilmiştir.

\section{Araştırmaya Katılanların Sosyo-Demografik Verileri}

Çalışmada, araştırmaya dâhil olan 347 sosyal medya kullanıcısının yaşları, cinsiyetleri, medeni durumları, çalışma durumları, aylık gelir durumları, aile aylık gelir durumları ve algılanan gelir düzeyleri gibi demografik özelikleri incelenmektedir. Bu verilere göre araştırmaya dâhil olan 347 sosyal medya kullanıcısının 122'si (\%35,2) erkek, 225'i (\%64,8) kadındır. Araştırmaya katılanların \% 19,6'sı 20 ve altı yaşları aralığında, \%55,9'u 21-24 yaşları aralığında, \%24,5'i ise 25 ve üzeri yaş aralığındadır. Katıımcıların medeni durumları incelendiğinde \%90,8'inin bekâr \%9,2'sinin ise evli olduğu gözükmektedir. Ankete dâhil olan katıımcıların \%37,8'i çalışmakta, \%62,2'si çalışmamaktadır. Anket katıımcılarının aylık gelir durumlarına bakıldığı zaman \%50,4'ünün 1000 ve altı gelir düzeyinde yoğunlaştığı görülmektedir. Katılımcıların aile aylık gelir durumları incelendiğinde ise \%49,9'unun 3001-6000 gelir düzeyinde yoğunlaştığı görülmektedir. Araştırmaya katılan sos- 
yal medya kullanıcılarının algılanan gelir düzeyleri \%21,9 düşük, \%66,9 orta ve $\% 11,2$ yüksek şeklinde dağılmaktadır.

Çalışmada ayrıca araştırmaya katılanların Instagram kullanım değerlendirmeleri incelenmiştir. Bu değerlendirmede, araştırmaya dâhil olan 347 sosyal medya kullanıcısının Instagram'da takip ettikleri mikro e-etkileyici kişilere karşı tutumları belirlemeye yönelik oluşturulan, günlük Instagram kullanım sıklıklarını, Instagram'da kaç mikro e-etkileyici kişiyi takip ettiklerini, mikro e-etkileyici kişileri güvenli bulma durumlarını ve mikro e-etkileyici kişi tarafından önerilen bir ürünü alma durumlarını içeren bilgiler yer almaktadır. Bu verilere göre, araştırmaya katılan Instagram kullanıcılarının günlük Instagram kullanım süresinin \%62,2 ile 1 ile 3 saat arasında yoğunlaştığı belirlenmiştir. Araştırmaya katılanların Instagram'da kaç tane mikro e-etkileyici kişiyi takip ettikleri incelendiğinde \%47,8'inin 1-3 kişi arasında yoğunlaştığı görülmektedir. Katılımcıların mikro e-etkileyici kişileri güvenli bulma durumları \%30 evet, \%60,2 hayır, \% 7,8 bazen olarak belirlenmiştir. Araştırmaya katılan Instagram kullanıcılarının mikro e-etkileyici kişi tarafından önerilen bir ürünü \%27,1'inin satın aldıkları, \% 72,9'unun ise satın almadıkları belirlenmiştir.

\section{Ölçeklere Ait Ortalama ve Standart Sapma Değerleri}

Tablo 2'te görüldüğü gibi katılımcıların "mikro e-etkileyici kişi kullanımının marka tutumu üzerindeki rolü" puan ortalamasının "orta" 2,894 $\pm 0,789$ (Min=1; Maks=5) olduğu tespit edilmiştir.

Tablo 2. Mikro E-Etkileyici Kişi Kullanımının Marka Tutumuna Yansıması Puan Ortalaması

\begin{tabular}{llllll}
\hline & N & Ort & Ss & Min. & Max. \\
\hline Mikro E-Etkileyiei & 347 & 2,894 & 0,789 & 1,000 & 5,000 \\
$\begin{array}{l}\text { Kişi Kullanmmin } \\
\text { Marka Tutumu }\end{array}$ & & & & & \\
Ûzerindeki Rolü & & & & & \\
\hline
\end{tabular}

Tablo 3. Mikro E-Etkileyici Kişi Kullanımının Marka Tutumuna Yansıması Puanlarının Katıımcının Ailesinin Sahip Olduğu Aylık Gelire Göre Ortalama Farkııı̆ı

\begin{tabular}{|c|c|c|c|c|c|c|}
\hline & Grup & $\mathbf{N}$ & Ort & Ss & $\mathbf{F}$ & $\mathbf{p}$ \\
\hline \multirow{3}{*}{$\begin{array}{l}\text { Mikro E-Ettkileyici Kişi } \\
\text { Kullanmmin Marka } \\
\text { Tutumu Ûzerindeki Rolū }\end{array}$} & $3000 \mathrm{Ve}$ Alt & 70 & 3,008 & 0,792 & \multirow[t]{3}{*}{0,934} & \multirow[t]{3}{*}{0,394} \\
\hline & $3001-6000$ & 173 & 2,859 & 0,735 & & \\
\hline & $6001 \mathrm{Ve}$ Üzeri & 104 & 2.875 & 0.871 & & \\
\hline
\end{tabular}

Tek Yönlü Varyans Analizi 
Araştırmaya katılan kişilerin mikro e-etkileyici kişi kullanımının marka tutumuna yansıması ortalamalarının araştırma kapsamında bir başka değişken olan "aile aylık geliri" kapsamında farklılaşıp farklılaşmadığını tespit edebilmek için ANOVA testi uygulanmıştır. Yapılan analiz sonucu gruplar arasında anlamlı bir farklılaşma olduğu saptanmamıştır ( $p>0.05$ ). Edinilen sonuçlar bağlamında; "H1a: Mikro e-etkileyici kişi kullanımının marka tutumuna yansıması ile tüketicilerin ailelerinin aylık gelir durumları arasında anlamlı bir farklılık vardır." hipotezi desteklenmemektedir.

Tablo 4. Mikro E-Etkileyici Kişi Kullanımının Marka Tutumuna Yansıması Puanlarının Algılanan Gelir Durumuna Göre Ortalama Farklılığı

\begin{tabular}{|c|c|c|c|c|c|c|}
\hline & Grup & $\mathbf{N}$ & Ort & Ss & $\mathbf{F}$ & $\mathbf{p}$ \\
\hline \multirow{3}{*}{$\begin{array}{l}\text { Mikro E-Etkileyici Kişi } \\
\text { Kullanumun Marka } \\
\text { Tutumu Ûzerindeki Rolu }\end{array}$} & Düşūk & 76 & 2,885 & 0,711 & \multirow[t]{3}{*}{1,218} & \multirow[t]{3}{*}{0,297} \\
\hline & Orta & 232 & 2,866 & 0,792 & & \\
\hline & Yüksek & 39 & 3,078 & 0,907 & & \\
\hline
\end{tabular}

Tek Yönlü Varyans Analizi

Katılımcıların mikro e-etkileyici kişi kullanımının marka tutumuna yansıması puanlarının "algılanan gelir düzeyi" değişkeni bağlamında anlamlı bir şekilde farklılaştı̆̆ı görülmemektedir ( $p>0.05$ ). Bu sebeple; "H1b: Mikro e-etkileyici kişi kullanımının marka tutumuna yansıması ile tüketicilerin algıladıkları gelir durumları arasında anlamlı bir farklılık vardır." hipotezi desteklenmemektedir.

Tablo 5. Mikro E-Etkileyici Kişi Kullanımının Marka Tutumuna

Yansıması Puanlarının Katılımcının Aylık Gelirine Göre Ortalama Farklıı̆ı

\begin{tabular}{|c|c|c|c|c|c|c|}
\hline & Grup & $\mathrm{N}$ & Ort & Ss & $\mathbf{F}$ & p \\
\hline \multirow{4}{*}{$\begin{array}{c}\text { Mikro E-Etkileyiei Kiși } \\
\text { Kullanummun Marka } \\
\text { Tutumu Ûzerindeki } \\
\text { Rolï }\end{array}$} & 1000 Ve Alt & 175 & 2,856 & 0,728 & \multirow[t]{4}{*}{0,434} & \multirow[t]{4}{*}{0,728} \\
\hline & $1001-2000$ & 91 & 2,934 & 0.841 & & \\
\hline & $2001-3000$ & 37 & 2,997 & 0,972 & & \\
\hline & 3001 Ve Uzeri & 44 & 2,876 & 0,760 & & \\
\hline
\end{tabular}

\section{Tek Yönlü Varyans Analizi}

Katılımcıların mikro e-etkileyici kişi kullanımının marka tutumuna yansıması puanlarının "kişisel aylık gelir durumu" değişkeni bağlamında anlamlı bir farklılaşma göstermediği saptanmıştır ( $p>0.05)$. Bu doğrultuda; "H1c: Mikro e-etkileyici kişi kullanımının marka tutumuna yansıması ile tüketicilerin aylık gelir durumları arasında anlamlı bir farklılık vardır." hipotezi desteklenmemektedir. Bu veriler bağlamında, mikro e-etkileyici kişi kullanımının marka tutumuna yansıması puanları ortalamalarının "aile aylık geliri", "algılanan gelir düzeyi" ve "aylık gelir" değişkenleri bağlamında anlamlı düzeyde bir farklılaşma göstermemesi, gelir du- 
rumunun mikro e-etkileyici kişi kullanımında katılımcıların markaya yönelik tutumunu etkilemediğini göstermektedir.

Tablo 6. Mikro E-Etkileyici Kişi Kullanımının Marka Tutumuna Yansıması Puanlarının Yaş Değişkeni Bağlamında Ortalama Farklılığı

\begin{tabular}{|c|c|c|c|c|c|c|}
\hline & Grup & $\mathrm{N}$ & Ort & Ss & $\mathbf{F}$ & p \\
\hline \multirow{3}{*}{$\begin{array}{c}\text { Mikro E-Etkileyici Kişi } \\
\text { Kullanummun Marka Tutumu } \\
\text { Ũzerindeki Rolū }\end{array}$} & $20 \mathrm{Ve}$ Alt & 68 & 2,830 & 0,739 & \multirow[t]{3}{*}{1,088} & \multirow[t]{3}{*}{0,338} \\
\hline & $21-24$ & 194 & 2,949 & 0,833 & & \\
\hline & $25 \mathrm{Ve}$ Ũzeri & 85 & 2.819 & 0.722 & & \\
\hline
\end{tabular}

Tek Yönlü Varyans Analizi

Katılımcıların mikro e-etkileyici kişi kullanımının marka tutumuna yansıması puanları "yaş değişkeni" bağlamında anlamlı bir farklılık göstermemektedir ( $p>0.05$ ). Anket katılımcılarının yaşları ve mikro e-etkileyici kişilerin kullanıldığı iletişim kampanyalarındaki markalara yönelik tutumları arasında fark bulunmaması sebebiyle; "H1d: Mikro e-etkileyici kişi kullanımının marka tutumuna yansıması ile tüketicilerin yaşları arasında anlamlı bir farklılık vardır." hipotezi desteklenmemektedir.

Tablo 7. Mikro E-Etkileyici Kişi Kullanımının Marka Tutumuna Yansıması Puanlarının Cinsiyet değişkeni Bağlamında Ortalama Farklı̆ı̆ı

\begin{tabular}{|c|c|c|c|c|c|c|c|}
\hline & Grup & $\mathbf{N}$ & Ort & Ss & $\mathbf{T}$ & sd & p \\
\hline \multirow{2}{*}{$\begin{array}{c}\text { Mikro E-Etkileyiei Kişi } \\
\text { Kullanuminn Marka Tutumu } \\
\text { Ôzerindeki Rolü }\end{array}$} & Erkek & 122 & 2,756 & 0,857 & \multirow[t]{2}{*}{$-2,410$} & \multirow[t]{2}{*}{345} & \multirow[t]{2}{*}{0,016} \\
\hline & Kadin & 225 & 2,969 & 0,741 & & & \\
\hline
\end{tabular}

Araştırmaya katılan kişilerin mikro e-etkileyici kişi kullanımının marka tutumuna yansıması puanlarının "cinsiyet değişkeni" bağlamında ortalama farkılığını tespit edebilme adına T-Testi'den yararlanılmıştır. Analiz sonucunda, gruplar arasında anlamlı bir farklılık olduğu yönünde bulgulara ulaşılmıştır $\left(t_{(345)=-} 2.410\right.$; $p=0.016<0,05)$. Kadın katılımcıların mikro e-etkileyici kişi kullanımının marka tutumuna yansıması puanları $(\dot{x}=2,969)$, erkek katılımcıların mikro e-etkileyici kişi kullanımının marka tutumuna yansıması puanlarından $(\dot{x}=2,756)$ yüksek bulunmuştur. Elde edilen veriler sonucunda; "H1e: Mikro e-etkileyici kişi kullanımının marka tutumuna yansıması ile tüketicilerin cinsiyetleri arasında anlamlı bir farklıık vardır." hipotezi desteklenmektedir. 
Tablo 8. Mikro E-Etkileyici Kişi Kullanımının Marka Tutumuna Yansıması Puanlarının Katıımcıların Medeni Durumu Bağlamında Ortalama Farklılıkları

\begin{tabular}{|c|c|c|c|c|c|c|c|}
\hline & Grup & $\mathbf{N}$ & Ort & Ss & $t$ & sd & p \\
\hline \multirow{2}{*}{$\begin{array}{c}\text { Mikro E-Etkileyici Kişi } \\
\text { Kullanımmun Marka Tutumu } \\
\text { Ûzerindeki Rolï }\end{array}$} & Evli & 32 & 3,013 & 0,655 & \multirow[t]{2}{*}{0,899} & \multirow[t]{2}{*}{345} & \multirow[t]{2}{*}{0,369} \\
\hline & Bekâr & 315 & 2,882 & 0,802 & & & \\
\hline
\end{tabular}

Baḡımsız Gruplar T-Testi

Katıımcıların mikro e-etkileyici kişi kullanımının marka tutumuna yansıması puan ortalamaları "medeni durum" değişkeni bağlamında anlamlı bir şekilde farklılaşmamaktadır $(p>0,05)$. Söz konusu sebeple; "H1f: Mikro e-etkileyici kişi kullanımının marka tutumuna yansıması ile tüketicilerin medeni durumları arasında anlamlı bir farklılık vardır." hipotezi desteklenmemektedir.

Tablo 9. Mikro E-Etkileyici Kişi Kullanımının Marka Tutumuna Yansıması Puanlarının Çalışma Durumu Değişkeni Bağlamında Ortalama Farklılı̆ı

\begin{tabular}{|c|c|c|c|c|c|c|c|}
\hline & Grup & $\mathbf{N}$ & Ort & Ss & $t$ & sd & $\mathbf{P}$ \\
\hline \multirow{2}{*}{$\begin{array}{c}\text { Mikro E-Ekkileyici Kişi } \\
\text { Kullanmının Marka Tutumu } \\
\text { Üzerindeki Rolü }\end{array}$} & Evet & 131 & 2,942 & 0,759 & \multirow[t]{2}{*}{0,883} & \multirow[t]{2}{*}{345} & \multirow[t]{2}{*}{0,378} \\
\hline & Hays & 216 & 2,865 & 0,808 & & & \\
\hline
\end{tabular}

Bağımsız Gruplar T-Testi

Katılımcıların mikro e-etkileyici kişi kullanımının marka tutumuna yansıması puan ortalamaları "çalışma durumu" değişkeni bağlamında anlamlı bir biçimde farklılaşmamaktadır ( $p>0,05)$. Bu nedenle; "H1g: Mikro e-etkileyici kişi kullanımının marka tutumuna yansıması ile tüketicilerin çalışma durumları arasında anlamlı bir farklıık vardır." hipotezi desteklenmemektedir.

Elde edilen veriler sonucunda; "H1: Mikro e-etkileyici kişi kullanımının marka tutumuna yansıması ile tüketicilerin demografik durumları arasında anlamlı bir farklılık vardır." hipotezinden H1e desteklenmekte; H1a, H1b, H1c, H1d, H1f ve H1g desteklenmemektedir.

Tablo 10. Mikro E-Etkileyici Kişi Kullanımının Marka Tutumuna Yansıması Puanlarının Günlük Instagram Kullanma Sıklığı Değişkeni Kapsamında Ortalama Farklılığı

\begin{tabular}{|c|c|c|c|c|c|c|c|}
\hline & Grup & $\mathbf{N}$ & Ort & Ss & $\mathbf{F}$ & $\mathbf{p}$ & Fark \\
\hline \multirow{3}{*}{$\begin{array}{l}\text { Mikro E-Etkileyici Kiģi } \\
\text { Kullanımunin Marka } \\
\text { Tutumu Ûzerindeki } \\
\text { Rola }\end{array}$} & $\begin{array}{l}\text { Hiç Veya } \\
\text { 1saatten Az }\end{array}$ & 51 & 2,679 & 0,810 & \multirow[t]{3}{*}{3,106} & \multirow[t]{3}{*}{0,046} & \multirow[t]{3}{*}{$3>1$} \\
\hline & 1-3 Saat & 216 & 2.894 & 0.796 & & & \\
\hline & 4 Saat Ve Ûzeri & 80 & 3,029 & 0,737 & & & \\
\hline
\end{tabular}


Katılımcıların günlük Instagram kullanma sıklığı değişkeni bağlamında mikro e-etkileyici kişi kullanımının marka tutumuna yansıması puan ortalamaları anlamlı düzeyde farklılık sergilemektedir $\left(F_{(2,344)}=3,106 ; p=0,046<0.05\right)$. Söz konusu farklılaşmanın nedeni ise; Günlük Instagram kullanma sıklığı 4 saat ve üzeri olanların mikro e-etkileyici kişi kullanımının marka tutumuna yansıması puanlarının $(\dot{x}=3,029)$, günlük Instagram kullanma sıklığı hiç veya 1 saatten az olanların mikro e-etkileyici kişi kullanımının marka tutumuna yansıması puanlarından $(\dot{\mathrm{x}}=2,679)$ yüksek olmasıdır. Elde edilen bulgular sonucunda; "H2: Mikro e-etkileyici kişi kullanımının marka tutumuna yansıması ile tüketicilerin günlük Instagram kullanma sıklığı arasında anlamlı bir farklılık vardır." hipotezi desteklenmektedir.

Tablo 11. Mikro E-Etkileyici Kişi Kullanımının Marka Tutumuna Yansıması Puanlarının Katıımcının Instagram'da Mikro E-Etkileyici Kişi Takip Sayısı Bağlamında Ortalama Farkııı̆ı

\begin{tabular}{|c|c|c|c|c|c|c|c|}
\hline & Grup & $\mathrm{N}$ & Ort & Ss & $\mathbf{F}$ & p & Fark \\
\hline \multirow{4}{*}{$\begin{array}{c}\text { Mikro E-Etkileyici Kişi } \\
\text { Kullanımınn Marka } \\
\text { Tutumu Ûzzerindeki } \\
\text { Rolü }\end{array}$} & 1-3 Kişi & 166 & 2.742 & 0.876 & \multirow[t]{4}{*}{4,057} & \multirow[t]{4}{*}{0,007} & $2>1$ \\
\hline & 4-6 Kişi & 69 & 3.017 & 0.687 & & & $3>1$ \\
\hline & 7.9 Kişi & 35 & 3,029 & 0,567 & & & $4>1$ \\
\hline & 10 Kişi Ve Üzeri & 77 & 3,050 & 0,711 & & & \\
\hline
\end{tabular}

Tek Yönlü Varyans Analizi

Anket katılımcılarının Instagram mecrasında kaç tane mikro e-etkileyici kişinin takip edildiğine göre mikro e-etkileyici kişi kullanımının marka tutumuna yansıması puan ortalamaları anlamlı düzeyde farklılık sergilemektedir $(F(3,343)=4,057$; $p=0,007<0.05)$. Söz konusu farklılaşmanın sebebi ise; Instagram'da kaç mikro e-etkileyici kişi takip edildiği 4-6 kişi olanların mikro e-etkileyici kişi kullanımının marka tutumuna yansıması puanlarının ( $\dot{x}=3,017)$, Instagram'da kaç mikro e-etkileyici kişi takip edildiği 1-3 kişi olanların mikro e-etkileyici kişi kullanımının marka tutumuna yansıması puanlarından $(\dot{x}=2,742)$ yüksek olmasıdır. Instagram'da kaç mikro e-etkileyici kişi takip edildiği 7-9 kişi olanların mikro e-etkileyici kişi kullanımının marka tutumuna yansıması puanlarının $(\dot{x}=3,029)$, Instagram'da kaç mikro e-etkileyici takip edildiği 1-3 kişi olanların mikro e-etkileyici kişi kullanımının marka tutumuna yansıması puanlarından ( $\dot{x}=2,742)$ yüksek olmasıdır. Instagram'da kaç mikro e-etkileyici kişi takip edildiği 10 kişi ve üzeri olanların mikro e-etkileyici kişi kullanımının marka tutumuna yansıması puanlarının ( $\dot{\mathrm{x}}=3,050)$, Instagram'da kaç mikro e-etkileyici kişi takip edildiği 1-3 kişi olanların mikro e-etkileyici kişi kullanımının marka tutumuna yansıması puanlarından $(\dot{\mathrm{x}}=2,742)$ yüksek olmasıdır. $\mathrm{Bu}$ veriler doğrultusunda; "H3: Mikro e-etkileyici kişi kullanımının marka tutumuna yansıması ile tüketicilerin Instagram'da takip ettiği mikro e-etkileyici kişi sayısı arasında anlamlı bir farklılık vardır." hipotezi desteklenmektedir. 
Tablo 12. Mikro E-Etkileyici Kişi Kullanımının Marka Tutumuna Yansıması Puanlarının Katılımcıların Mikro E-Etkileyici Kişileri Güvenli Bulma Durumları Bağlamında Ortalama Farklıı̆ı

\begin{tabular}{|c|c|c|c|c|c|c|c|}
\hline & Grup & $N$ & Ort & Ss & $\mathbf{F}$ & p & Fark \\
\hline \multirow{3}{*}{$\begin{array}{l}\text { Mikro E-Etkileyici Kiģi } \\
\text { Kullanmman Marka } \\
\text { Tutumu Ozerindeki Rolu }\end{array}$} & Evet & 111 & 3,303 & 0,678 & \multirow{3}{*}{26,190} & \multirow[t]{3}{*}{0,000} & $1>2$ \\
\hline & Hayr & 209 & 2.677 & 0.770 & & & $1>3$ \\
\hline & Bazen & 27 & 2.892 & 0.715 & & & \\
\hline
\end{tabular}

Katılımcıların mikro e-etkileyicileri güvenli bulma durumuna göre mikro e-etkileyici kişi kullanımının marka tutumuna yansıması puan ortalamaları istatistiksel açıdan anlamlı bir şekilde farklılık sergilemektedir $\left(F_{(2,344)}=26,190 ; p=0,000<0.05\right)$. Söz konusu farkın sebebi ise; mikro e-etkileyici kişileri güvenli bulma durumu evet olanların mikro e-etkileyici kişi kullanımının marka tutumuna yansıması puanlarının ( $\dot{x}=3,303)$, mikro e-etkileyici kişileri güvenli bulma durumu hayır olanların mikro e-etkileyici kişi kullanımının marka tutumuna yansıması puanlarından $(\dot{x}=2,677)$ yüksek olmasıdır. Mikro e-etkileyici kişileri güvenli bulma durumu evet olanların mikro e-etkileyici kişi kullanımının marka tutumuna yansıması puanlarının $(\dot{x}=3,303)$, mikro e-etkileyici kişileri güvenli bulma durumu bazen olanların mikro e-etkileyici kişi kullanımının marka tutumuna yansıması puanlarından $(\dot{x}=2,892)$ yüksek olmasıdır. Bu doğrultuda; "H4: Mikro e-etkileyici kişi kullanımının marka tutumuna yansıması ile tüketicilerin mikro e-etkileyici kişileri güvenli bulmaları arasında anlamlı bir farklılık vardır." hipotezi desteklenmektedir.

Tablo 13. Mikro E-Etkileyici Kişi Kullanımının Marka Tutumuna Yansıması Puanlarının Mikro E-Etkileyici Kişi Tarafından Önerilen Ürünü Alma Durumu Bağlamında Ortalama Farklılı̆ı

\begin{tabular}{|c|c|c|c|c|c|c|c|}
\hline & Grup & $\mathrm{N}$ & Ort & Ss & $t$ & sd & $\mathbf{P}$ \\
\hline \multirow{2}{*}{$\begin{array}{c}\text { Mikro E-Etkileyiei Kişi } \\
\text { Kullanmmun Marka Tutumu } \\
\text { Ôzerindeki Rolū }\end{array}$} & Evet & 94 & 3,380 & 0,567 & \multirow[t]{2}{*}{7,536} & \multirow[t]{2}{*}{345} & \multirow[t]{2}{*}{0,000} \\
\hline & Hayır & 253 & 2,713 & 0,785 & & & \\
\hline
\end{tabular}

Bağımsız Gruplar T-Testi

Katılımcıların mikro e-etkileyici kişi tarafından önerilen ürünü almaya göre mikro e-etkileyici kişi kullanımının marka tutumuna yansıması puan ortalamaları anlamlı bir şekilde farklılaşmaktadır $\left(\mathrm{t}_{(345)}=7.536 ; \mathrm{p}=0.000<0,05\right)$. Mikro e-etkileyici kişi tarafından önerilen ürünü alanların mikro e-etkileyici kişi kullanımının marka tutumuna yansıması puanları $(\dot{x}=3,380)$, mikro e-etkileyici kişi tarafından önerilen ürünü almayanların mikro e-etkileyici kişi kullanımının marka tutumuna yansıması puanlarından $(\dot{\mathrm{x}}=2,713)$ yüksek bulunmuştur. Elde edilen sonuçlar bağlamında; "H5: Mikro e-etkileyici kişi kullanımının marka tutumuna yansıması ile tüketicilerin mikro e-etkileyici kişi tarafından önerilen ürünü almaları arasında anlamlı bir farklılık vardır." hipotezi desteklenmektedir. 


\section{Tartışma ve Sonuç}

Son yüzyılda her geçen gün hızla gelişen teknolojik devrim her alanı etkilediği gibi pazarlama anlayışını da etkilemiştir. Özellikle internetin her alanda kullanılmaya başlanması, tüketicilerin satın alma karar süreçlerinde daha çok bilgiye hızlı bir şekilde ulaşabilmesine olanak sağlamış ve bu nedenle markalar arasında rekabet yoğunlaşmıştır. Bu yoğunlaşan rekabet sebebiyle işletmeler geleneksel pazarlama yöntemlerinin yanı sıra dijital pazarlama yöntemlerini de kullanmaya başlamıştır. Bu bağlamda, tüketicilerin en çok yakın çevresinden etkilendiğini varsayan ağızdan ağıza pazarlama yöntemi yerini dijital ortamda gerçekleştirilen "e-etkileyici kişi" pazarlamasına bırakmıştır. Tüketiciler iletişim kampanyalarında kullanılan, karşııklı diyaloga girebildikleri mikro düzeyde takipçisi bulunan kişilerden etkilenerek markaya yönelik tutumlarını değiştirebilmektedir. Mikro e-etkileyici kişilerin marka tutumuna yansımasının benzer özelliklere sahip farklı tüketici grupları arasında farklılık gösterip göstermediğinin belirlenmesi, doğru hedef kitleye en uygun mesajla ulaşmak açısından önem taşımaktadır. Bu doğrultuda gerçekleştirilen çalışmada; iletişim kampanyalarında kullanılan mikro e-etkileyici kişilerin marka tutumuna yansımasıyla, tüketicilerin demografik durumları, günlük Instagram kullanma sıklıkları, Instagram'da kaç tane mikro e-etkileyici kişiyi takip ettikleri, mikro e-etkileyici kişileri güvenilir bulma durumları ve mikro e-etkileyici kişilerin önerdikleri bir ürünü satın alma durumları arasında farklılık bulunup bulunmadığı incelenmesi esas alınmıştır.

Araştırma sonucunda, tüketicilerin demografik özelliklerinden gelir durumları, yaşları, medeni durumları ve çalışma durumları değişkenleri ile kullanılan mikro e-etkileyici kişilerin marka tutumuna yansımasına dair anlamlı bir farkın olmadığı sonucuna varımıştır. Ancak, çalışmada, katılımcıların demografik özellikleri arasında olan cinsiyet değişkeni ile iletişim kampanyalarında kullanılan mikro e-etkileyici kişilerin marka tutumuna yansıması arasında anlamlı bir farkın olduğu gözlemlenmektedir. Bu bağlamda elde edilen sonuçlar doğrultusunda, kadınların iletişim kampanyalarında mikro e-etkileyici kişi kullanan markaları, erkeklere göre daha olumlu değerlendirdiği sonucuna ulaşılmıştır.

Araştırma sonucunda katılımcıların günlük Instagram kullanma sıklığı değişkeni analiz edildiğinde anlamlı bir farka rastlanmıştır. Bu bağlamda, günlük Instagram kullanma sıklığı 4 saat ve üzeri olan katılımcıların günlük Instagram kullanma sıklığı hiç veya bir saatten az olan katılımcılara göre mikro e-etkileyici kişilerin kullanıldığı iletişim kampanyalarındaki markalara yönelik tutumlarında değişim olduğu göze çarpmaktadır. Sonuç olarak, Instagram'da çok zaman harcayan tüketicilerin daha az zaman harcayan tüketicilere göre mikro e-etkileyici kullanan markalara karşı olumlu bir tutum sergiledikleri söylenebilmektedir.

Araştırmada, katıımcıların mikro e-etkileyici kişi kullanımının marka tutumuna yansıması puanları ortalamalarının Instagram'da kaç tane mikro e-etkileyici kişiyi takip ettikleri değişkenine göre farklılığın anlamlı olduğu gözlenmiştir. Elde 
edilen sonuçlar bağlamında, Instagram'da 10 kişi ve üzerinde mikro e-etkileyici kişiyi takip eden tüketicilerin daha az mikro e-etkileyici kişiyi takip eden tüketicilere göre mikro e-etkileyici kişilerin kullanıldığı iletişim kampanyalarındaki markalara yönelik tutumlarının olumlu yönde olduğu söylenebilmektedir.

Araştırmada, katıımcıların mikro e-etkileyici kişileri güvenilir kişiler olarak görme değişkenleri ile iletişim kampanyalarında kullanılan mikro e-etkileyici kişilerin marka tutumuna etkisi arasındaki farklıı̆ın anlamlı olduğu sonucuna ulaşımıştır. Tüketiciler karşııklı diyaloga girebildikleri mikro e-etkileyici kişileri arkadaşları olarak algılamaktadır. Bu bağlamda, bu kişilere güven duyarak bu kişilerden aldıkları ürün tavsiyelerine karşı olumlu bir tutum sergilediği söylenilebilmektedir. Dolayısıyla işletmelerin markalarına uygun mikro e-etkileyici kişiyi belirlerken güven faktörünü dikkate alması gerekmektedir. Böylece marka ile mikro-etkileyici kişi arasında tüketici zinninde bir bağ kurulup markaya yönelik tutumlarının daha olumlu olabileceği sonucuna ulaşılabilmektedir. İlaveten mikro e-etkileyici kişi güvenilirliğinin önemli bir etkisi olması sebebiyle, işletmeler kısa vadeli pazarlama hedeflerine ulaşmaya odaklanmak yerine uzun vadede marka itibarlarını oluşturmaya ve yönetmeye odaklanmaları gerektiği düşünülmektedir.

Ayrıca araştırmaya katılan tüketicilerin mikro e-etkileyici kişi kullanımının marka tutumuna yansıması puanları ortalamalarının mikro e-etkileyici kişiler tarafından önerilen bir ürünü satın alma değişkenine göre farklıığın anlamlı olduğu gözlenmiştir. Elde edilen veriler doğrultusunda, mikro e-etkileyici kişilerin tavsiye ettikleri ürünlerden satın alan tüketicilerin, mikro e-etkileyici kişilerin tanıttıkları markaları olumlu yönde değerlendirdikleri söylenilebilmektedir. Bu bağlamda, markaların mevcut tüketicilere yönelik stratejilerini geliştirerek ve potansiyel müşterilerin markanın ürünlerini kullanması için yeni stratejiler oluşturarak markaya yönelik tutumun olumlu olmasını sağlayabilecekleri sonucuna ulaşılmaktadır.

E-etkileyici kişi pazarlaması yapan işletmelerin amaçları doğrultusunda hangi e-etkileyici kişi türüyle çalışması gerektiği önem arz etmektedir. Ayrıca, dijitalleşen dünya ile birlikte Türkiye'de ve dünyanın birçok ülkesinde yeni bir yöntem olarak kullanılan mikro e-etkileyici kişi pazarlamasının önümüzdeki yıllarda markalar tarafından daha çok kullanılması güçlü bir olasılıktır. Bu nedenle araştırmanın, tüketicilerin Instagram'daki iletişim kampanyalarında mikro e-etkileyici kişi kullanan markalara yönelik olan tutumlarının anlaşılmasında ve bu doğrultuda yapılacak çalışmalarda markaların stratejilerini belirlemesinde, marka ve işletme yöneticileri için yol gösterici olduğu düşünülmektedir. Bu doğrultuda çalışmanın, ileride alanla ilgili yapılacak daha kapsamlı araştırmalara yol gösterici olması ve böylece literatüre katlı sunması umulmaktadır.

Yapılan çalışmanın literatürdeki araştırmalardan farklılaşan özelliği, tüketicilerin Instagram'daki iletişim kampanyalarında mikro e-etkileyici kişi kullanan markalara yönelik tutumlarının demografik durum ve Instagram kullanma sıklıkları değişkeni dışında Instagram'da takip ettikleri mikro e-etkileyici kişi sayısı, mik- 
ro e-etkileyici kişileri güvenilir bulma ve mikro e-etkileyici kişilerin önerdikleri bir ürünü satın alma durum değişkenleri ile ele alınmasıdır. Bu çalışmanın bir diğer özgün yanı ise, e-etkileyici kişi türlerinden yalnızca mikro e-etkileyici kişi kullanımına odaklanmış olmasıdır. Bu kapsamda özellikle işletmelere e-etkileyici kişi pazarlaması yaparken rehberlik sağlaması için genel bir e-etkileyici kişi pazarlamasının marka tutumu bağlamında irdelenmesinden ziyade tek bir türe odaklanılmıştır. Ayrıca bu çalışmanın literatürde yer alan mikro e-etkileyici kişi üzerine yapılan araştırmalardan farklılaşan özelliği, tüketicilerin Instagram'daki mikro e-etkileyici kişi kullanan markalara yönelik tutumları ile belirlenen değişkenler arasındaki ilişkinin de belirlenmesidir. Bu doğrultuda araştırma, tüketicilerin Instagram'da takip ettikleri kişi sayısı, mikro e-etkileyici kişileri güvenilir bulma durumları ve mikro e-etkileyici kişilerin tavsiye ettikleri ürünleri satın alma durumları ile mikro e-etkileyici kişileri kullanan markaya yönelik tutumları arasında anlamlı bir ilişki olması sonucuyla, literatürdeki diğer araştırmalardan farklılaşmaktadır. Bu bağlamda yapılan araştırma, literatürdeki e-etkileyici kişi pazarlamasını genel bir perspektiften ele alan Breves ve diğerleri (2019), Arora ve diğerleri (2019) ve Haenlein ve diğerlerinin (2020) yaptıkları çalışmalardan farklılık göstermektedir. Tüketicilerin cinsiyet ve Instagram kullanma sıklıkları ile mikro e-etkileyici kişi kullanan markaya yönelik tutumları arasında anlamlı bir ilişsinin olması, literatürde e-etkileyici kişi pazarlaması üzerine yapılan Yaylagül (2017) ve Kıran ve diğerlerinin (2019) çalışmaları ile benzer sonuçlara ulaşıldığını göstermektedir.

Yapılan bu çalışmanın yalnızca mikro e-etkileyici kişi kullanımına odaklaması nedeniyle mega ve makro e-etkileyici kişi kullanımı arasında karşılaştırmalı bir analiz sunmaması araştırmanın kısıını oluşturmaktadır. Ayrıca bu araştırmanın ana kütlesini yalnızca Instagram hesabı bulunan tüketicilerin oluşturması, araştırma örnekleminin 18-34 yaş grubu olması ve araştırma katılımcılarının sadece $\% 9,2$ 'sinin evli olması araştırmanın bir diğer kısıtını göstermektedir.

Gelecekte yapılacak olan çalışmalarda, diğer yaş grupları ve medeni durum gibi farklı demografik özellikleri olan kişiler araştırmaya dâhil edilerek bu araştırma gerçekleştirilebilir. Ayrıca, tüketicilerin Instagram'daki mikro e-etkileyici kişi kullanan markalara yönelik marka tutumlarının yanı sıra makro ve mega e-etkileyici kişi kullanan markalara yönelik tutumları ile belirlenen değişkenler arasındaki ilişkiyi irdeleyerek karşılaştırmalı bir analiz sunulabilir. Mikro e-etkileyici kişi kullanımının, Instagram çerçevesinde incelenmesinin dışında ileride yapılacak olan çalışmalarda, Facebook, Twitter, Youtube ve TikTok gibi günümüzde çok fazla kullanıcı sayısına sahip olan platformlardaki mikro e-etkileyici kişi kullanımın marka tutumu üzerindeki rolü incelenebilir. Ayrıca, mikro e-etkileyici kişi kullanımının tüketicilerin satın alma kararları üzerindeki etkisinin irdelenmesi de ileride yapılacak olan çalışmaların ana fikrini oluşturabilir. 


\section{Kaynakça}

Abidin, C. (2016). Visibility labour: Engaging with Influencers' fashion brands and \#OOTD advertorial campaigns on Instagram. Media International Australia, 161(1), 86-100.

Adams, N. (2016). Micro Influencers vs. Macro Influencers. 01 10, 2019 tarihinde www.linkedin.com: https://www.linkedin.com/pulse/micro-influencers-vs-macro-nicole-adams adresinden alındı

Ajzen, I. (2005). Attitudes, Personality and Behavior (Second Edition). New York : Open University Press.

Arora, A., Bansal, S., Kandpal, C., Aswani, R., \& Dwivedi, Y. (2019). Measuring social media influencer index- insights from facebook, Twitter and Instagram. Journal of Retailing and Consumer Services, 49, 86-101.

Avcılar, M. Y., \& Açar, F. (2017). Sosyal Medya Reklamlarında Ünlü Desteği Kullanımı: Mikro-Ünlülerin Yükselişi. 15. Uluslararası Türk Dünyası - Sosyal Bilimler Kongresi, (s. 1-14).

Baker, M. J., \& Churchill, G. A. (1977). The Impact of Physically Attractive Models on Advertising Evaluations. Journal of Marketing Research, 14(4), 538-555.

Barker, S. (2017, 01 03). The Ultimate Guide to Micro-Influencers. 01 09, 2019 tarihinde shanebarker.com: https://shanebarker.com/blog/micro-influencers-guide/ adresinden alındı

Batra, R., \& Ahtola, O. T. (1990). Measuring the Hedonic and Utilitarian Sources of Consumer Attitudes. Marketing Letters , 2(2), 159-170.

Beam, N., Chamberlin, B., Collins, J., Emerick, S., Fein, M., Laine, A., . . Naik, D. (2013). Influencer Guidebook. Word of Mouth Marketing Association.

Bhakar, S., Bhakar, S., \& Dubey, A. (2015). Analysis of the Factors Affecting Customers' Purchase Intention: The Mediating Role of Customer Knowledge and Perceived Value. Advances in Social Sciences Research Journal, 2(1), 87-101.

Boerman, S. C. (2020). The effects of the standardized instagram disclosure for micro- and meso-influencers. Computers in Human Behavior, 199-207.

Booth, N., \& Matic, J. A. (2011). Mapping and leveraging influencers in social media to shape corporate brand perceptions. Corporate Communications: An International Journal, 16(3), 184-191.

Breves, P. L., Liebers, N., Abt, M., \& Kunze, A. (2019). The Perceived Fit between Instagram Influencers and the Endorsed Brand: How Influencer-Brand Fit Affects Source Credibility and Persuasive Effectiveness. Journal of Advertising Research, 59(4), 440-454.

Brown, D., \& Fiorella, S. (2013). Influence Marketing - How to Create, Manage, and Measure Brand Infl uencers in Social Media Marketing. United States of 
America: Que Publishing.

Brown, D., \& Hayes, N. (2008). Influencer Marketing: Who Really Influences Your Customers? . Hungary: Elsevier Ltd.

Bruner, G. C., \& Kumar, A. (2000). Web Commercials and Advertising Hierarchy of Effects. Journal of Advertising Research, 35-42.

Deges, F. (2018). Quick Guide Influencer Marketing: Wie Sie durch Multiplikatoren mehr Reichweite und Umsatz erzielen. Brühl: Springer Gabler.

Djafarova, E., \& Rushworth, C. (2017). Exploring the credibility of online celebrities' Instagram profiles in influencing the purchase decisions of young female users. Computers in Human Behavior, 68, 1-7.

Dobele, A. (2002). Categories of Word-of-Mouth Referrers. ANZMAC 2002 Conference Proceedings, (s. 671-677). Melbourne.

Evans, N. J., Phua, J., Jun, H., \& Lim, J. (2017). Disclosing Instagram Influencer Advertising: The Effects of Disclosure Language on Advertising Recognition, Attitudes, and Behavioral Intent. Journal of Interactive Advertising, 17(2), 138-149.

Feick, L., \& Price, L. L. (1987, 01). The Market Maven: A Diffuser of Marketplace Information. Journal of Marketing, 51, 83-97.

Fuchs, C. (2016). Sosyal Medya: Eleştirel Bir Giriş. (D. S. IIlker Kalaycı, Çev.) Ankara: NotaBene Yayınları.

Gallegos, J. A. (2018, 01 03). Influencer Marketing: Understanding The Difference Between Micro-Influencers and Mega-Influencers. 01 08, 2019 tarihinde www.tintup.com: https://www.tintup.com/blog/micro-influencers-vs-mega-influencers-marketing/ adresinden alındı

Gedik, Y. (2020). Sosyal Medyada Yükselen Bir Trend: Influencer Pazarlama Üzerine Kavramsal Bir Değerlendirme. Pamukkale Üniversitesi İşletme Araştırmaları Dergisi, 7(2), 362-385.

Gegez, A. E. (2015). Pazarlama Araştırmaları. İstanbul: Beta Basım Yayım Dağııım A. Ş. .

Gottbrecht, L. (2016, 10 18). The Three Types of Influencers All Marketers Should Know. 01 07, 2019 tarihinde www.mavrck.co: https://www.mavrck.co/the-three-types-of-influencers-all-marketers-should-know-infographic/ adresinden alındı

Grafström, J., Jakobsson, L., \& Wiede, P. (2018). The Impact of Influencer Marketing on Consumers' Attitudes.

Grimm, P. E. (2005). Ab components' impact on brand preference. Journal of Business Research , $508-517$.

Haenlein, M. A., Farnsworth, T., Hugo, H., Hunichen, J., \& Welte, D. (2020). Navigating the New Era of Influencer Marketing: How to be Successful on Instagram, TikTok, \& Co. California Management Review, 63(1), 5-25. 
Influence.co. (2018, 02 19). Instagram Influencer Rates. 01 08, 2019 tarihinde blog.influence.co: http://blog.influence.co/instagram-influencer-rates/ adresinden alındı

Jahnke, M. (2018). Influencer Marketing: Für Unternehmen und Influencer: Strategien, Plattformen, Instrumente, rechtlicher Rahmen. Mit vielen Beispielen. Hamburg: Springer Gabler.

Kıran, S., Yılmaz, C., \& Emre, i. E. (2019). Instagram'daki Influencer'ların Takipçiler Üzerindeki Etkisi. Uluslararası Yönetim Bilişim Sistemleri ve Bilgisayar Bilimleri Dergisi, 100-111.

Kiecker, P., \& Cowles, D. (2001). Interpersonal Communication and Personal Influence on the Internet: A Framework for Examining Online Word-of-Mouth. Journal of Euromarketing, 11(2), 71-88.

Kim, E., Sung, Y., \& Kang, H. (2014). Brand followers' retweeting behavior on Twitter: How brand relationships influence brand electronic word-of-mouth. Computers in Human Behavior, 18-25.

Lee, S., \& Kim, E. (2020). Influencer marketing on Instagram: How sponsorship disclosure, influencer credibility, and brand credibility impact the effectiveness of Instagram promotional post. Journal of Global Fashion Marketing, 11(3), 232-249.

Linqia. (2017). The State Of Influencer Marketing 2018: A look into how brands and agencies view the future of influencer marketing. Linqia.

Markerly. (2016). Instagram Marketing: Does Influencer Size Matter? 01 08, 2019 tarihinde markerly.com: http://markerly.com/blog/instagram-marketing-does-influencer-size-matter/ adresinden alındı

Marwick, A. E. (2013). Status update: Celebrity, publicity, \& branding in the social media age. New Haven: Yale University Press.

Mavrck. (2016). The 7 Step Guide to Influencer Marketing. 01 07, 2019 tarihinde http://cdn2.hubspot.net/hubfs/392015/7_Steps_to_Influencer_Marketing_Mavrck_2016.pdf adresinden alındı

Mediakix. (2017, 06 21). Guide: The Pros \& Cons of Marketing With Micro-Influencers. 01 11, 2019 tarihinde mediakix.com: http://mediakix.com/2017/06/micro-influencers-pros-vs-cons-guide/\#gs.CNXWKF5A adresinden alındı

Mediakix. (2017, 06 02). How 7 Top Brands Used Instagram Micro-Influencer Campaigns. 01 11, 2019 tarihinde mediakix.com: https://mediakix.com/2017/06/ top-instagram-micro-influencer-campaigns/\#gs.IOebwoHQ adresinden alındı

Mert, Y. L. (2018). Dijital Pazarlama Ekseninde Influencer Marketing Uygulamaları. Gümüşhane Üniversitesi İletişim Fakültesi Eleltronik Dergisi, 6(2), 1299-1328.

Mitchell, A. A., \& Olson, J. C. (1981). Are Product Attribute Beliefs the Only Mediator of Advertising Effects on Brand Attitude? Journal of Marketing Research, 18(3), 318-332. 
Mothersbaugh, D. L., \& Hawkins, D. I. ( 2016). Consumer Behavior: Building Marketing Strategy (Thirteenth Edition). New York: McGraw-Hill Education.

Naresh, K. M., \& Birks, D. F. (2000). Marketing Research: An Applied Approach. Prentice Hall.

Neil, A. (2018, 04 09). Micro, Macro, and Mega Influencers: Understanding the Difference. 01 07, 2019 tarihinde https://www.liftlikes.com/micro-macro-mega-influencers-understanding-difference/: https://www.liftlikes.com/micro-macro-mega-influencers-understanding-difference/ adresinden alındı

Öztürk, E., \& Şener, G. (2018). Modada Nüfuz Pazarlaması: Mikro Instabloggerların Ürün Yerleştirme Uygulamaları. Selçuk Üniversitesi Illetişim Fakültesi Akademik Dergisi, 11(1), 382-412.

Peter, J. P., \& Olson, J. C. (2009). Consumer Behavior \& Marketing Strategy (Ninth Edition). New York: McGraw-Hill//rwin.

Reisinger, Y. (2009). International Tourism: Cultures and Behavior (First Edition). Hungary: Elsevier Ltd.

Sandoval, M. (2018, 05 10). Nano, Micro, Macro and Mega Influencers. What are these and which one is the correct option for my brand? 0107,2019 tarihinde www.godandbeauty.com: https://www.godandbeauty.com/blog/2018/5/10/nano-micro-macro-and-mega-influencers-what-are-these-and-which-one-is-the-correct-option-for-my-brand adresinden alındı

Schiffman, L. G., \& Wisenblit, J. L. (2015). Consumer Behavior. Eleventh Edition. London: Pearson Education Limited.

Silva, R. V., \& Alw, S. F. (2006). Cognitive, affective attributes and conative, behavioural responses in retail corporate branding. Journal of Product \& Brand Management, 15(5), 293 - 305.

Solomon, M. R. (2017). Consumer Behavior: Buying, Having, and Being (Twelfth Edition). England: Pearson Education Limited.

Spears, N., \& Singh, S. N. (2004). Measuring Attitude Toward the Brand and Purchase Intentions. Journal of Current Issues and Research in Advertising, 53-66.

Spry, A., Pappu, R., \& Cornwell, T. B. (2011). Celebrity endorsement, brand credibility and brand equity. European Journal of Marketing, 45(6), 882-909.

Statista. (2019). Distribution of Instagram users worldwide as of April 2019, by age group. 06 20, 2019 tarihinde www.statista.com: https://www.statista.com/ statistics/325587/instagram-global-age-group/ adresinden alındı

Sudha, M., \& Sheena, K. (2017). Impact of Influencers in Consumer Decision Process: the Fashion Industry. SCMS Journal of Indian Management, 14-30.

Sümbüloğlu, K. (1993). Biyoistatistik. Ankara: Özdemir Yayıncılık.

Towhidi, G., \& Sinha, A. P. (2015). Predicting Opinion Leaders in Word-of-Mouth 
Communities . Twenty-first Americas Conference on Information Systems, (s. 1-10). Puerto Rico.

Uyar, A. (2018). Reklamlarda Ünlü Kullanımın Tüketiciler Açısından Değerlendirilmesi. Anemon Muş Alparslan Üniversitesi Sosyal Bilimler Dergisi, 121-127.

Veirman, M. D., Cauberghe, V., \& Hudders, L. (2017). Marketing through Instagram influencers: the impact of number of followers and product divergence on brand attitude. International Journal of Advertising, 36(5), 798-828.

Walsh, G., Gwinner, K. P., \& Swanson, S. R. (2004). What makes mavens tick? Exploring the motives of market mavens' initiation of information diffusion. Journal of Consumer Marketing, 21(2), 109-122.

Yaylagül, Ş. (2017). Sosyal Medya Fenomenlerine Bağlanmışığın Belirlenmesi: Yükseköğretim Öğrencileri Üzerine Bir Uygulama. Adnan Menderes Üniversitesi, Sosyal Bilimler Enstitüsü Dergisi, 4(3), 219-235.

Yıldıım, A., \& Şimşek, H. (2016). Sosyal Bilimlerde Nitel Araştırma Yöntemleri. Ankara: Seçkin Yayıncılık San. ve Tic. A. Ş.

Zeren, D., \& Gökdaglı, N. (2020). Influencer Versus Celebrity Endorser Performance on Instagram. Strategic Innovative Marketing and Tourism (s. 695-704). içinde Springer. 